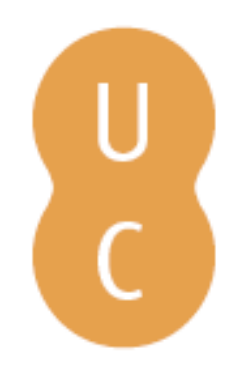

\title{
nommalina
}

\section{Lecturas alegórico-racionalistas de la leyenda de Medea}

Autor(es): Barrigón, Carmen

Publicado por: Imprensa da Universidade de Coimbra; Universidad de Valladolid

URL

persistente: URI:http://hdl.handle.net/10316.2/32307

DOI: $\quad$ DOI:http://dx.doi.org/10.14195/978-989-26-0472-5_7

Accessed : $\quad$ 26-Apr-2023 14:36:02

A navegação consulta e descarregamento dos títulos inseridos nas Bibliotecas Digitais UC Digitalis, UC Pombalina e UC Impactum, pressupõem a aceitação plena e sem reservas dos Termos e Condições de Uso destas Bibliotecas Digitais, disponíveis em https://digitalis.uc.pt/pt-pt/termos.

Conforme exposto nos referidos Termos e Condições de Uso, o descarregamento de títulos de acesso restrito requer uma licença válida de autorização devendo o utilizador aceder ao(s) documento(s) a partir de um endereço de IP da instituição detentora da supramencionada licença.

Ao utilizador é apenas permitido o descarregamento para uso pessoal, pelo que o emprego do(s) título(s) descarregado(s) para outro fim, designadamente comercial, carece de autorização do respetivo autor ou editor da obra.

Na medida em que todas as obras da UC Digitalis se encontram protegidas pelo Código do Direito de Autor e Direitos Conexos e demais legislação aplicável, toda a cópia, parcial ou total, deste documento, nos casos em que é legalmente admitida, deverá conter ou fazer-se acompanhar por este aviso.

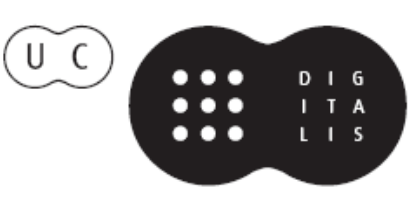


Emilio Suárez de la Torre

Maria do Céu Fialho

(Coordinadores)

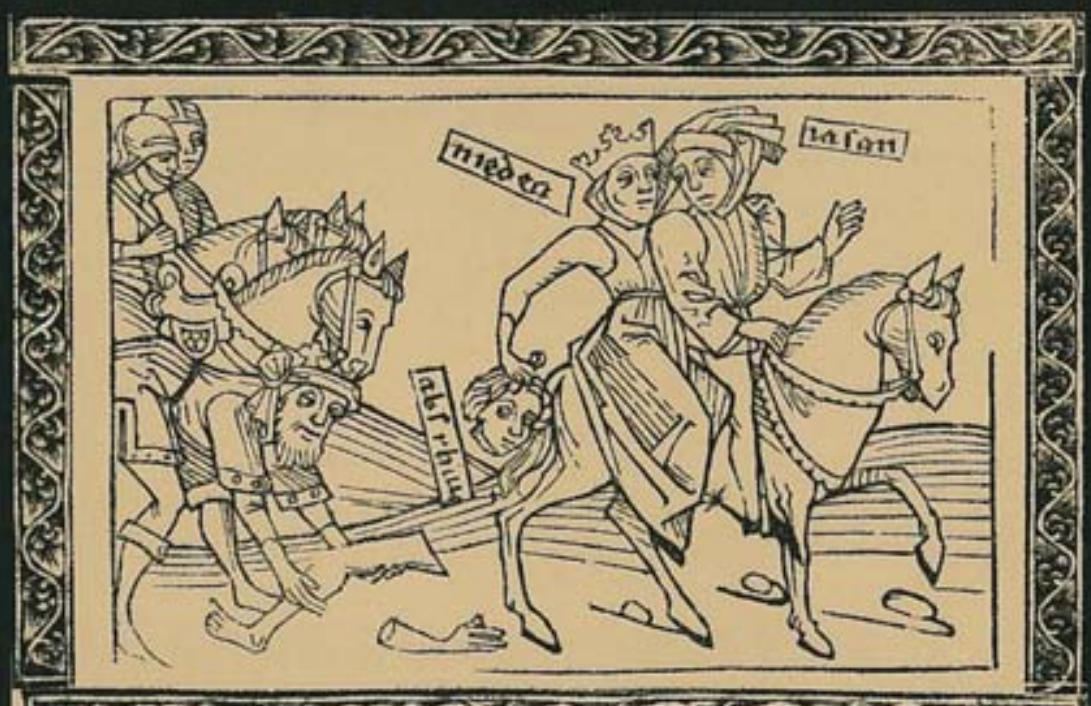

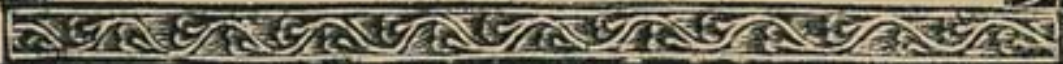

\section{BAJO EL SIGNO DE MEDEA}

\section{SOB O SIGNO DE MEDÉIA}




\section{Lecturas alegórico-racionalistas de la leyenda de Medea}

CARMEN BARRIGON

Universidad de Valladolid

En julio del año 2000, en el Festival de Teatro Clásico de Mérida, la actriz catalana Nuria Espert, que en esos momentos representaba el papel de Medea, declaraba: "Hasta la gente que nunca ha ido al teatro sabe quién es Medea. Es un personaje fascinante y cada vez más moderno. Al llegar la liberalización de la mujer a Medea se la ve de otra manera, supongo que en los siglos pasados se la veía como una loca vengativa, un monstruo; en cambio, ahora se la ve como una mujer ofendida, vejada, humillada, traicionada y que, desde luego, escoge una vía trágica [...]. Creo que ha ido tomando más complejidad y acercándose más y más a nuestros días" ${ }^{\prime 1}$. No van desencaminadas estas palabras. Desgraciadamente es moderna, su leyenda impacta, causa estupor y admiración al mismo tiempo, a todo aquel que alguna vez se ha acercado a este mito griego, y el modo de explicarlo, entenderlo y justificarlo ha ido variando con el paso de los siglos desde la Antigüedad clásica hasta nuestros días, en virtud de la heterogeneidad de las mentalidades que fueron acogiendo esta leyenda y en función de los distintos enfoques que se le han ido dando.

De todas las posibilidades de lectura a que ha dado lugar la leyenda de Medea, vamos a centrarnos en la exégesis alegórica. Estudiaremos los episodios más significativos que han sido objeto de este tipo de interpretación desde la Antigüedad hasta el siglo XVII, lo cual nos permitirá observar cómo se ha llevado a cabo, por qué autores, en qué épocas y hasta cuando. Pero antes de pasar a este análisis, es imprescindible detenernos en el desarrollo del mito y hacer unas consideraciones generales sobre la génesis de esta corriente tan sobresaliente de la Antigüedad Clásica.

(1) "El teatro me eligió a me", El Festival de Teatro de Mérida, 1, Mérida, julio, 2000, 15. 


\section{LA LEYENDA DE MEDEA}

El mito de Medea forma parte del complejo entramado de leyendas que conforma el mito de Jasón y los Argonautas ${ }^{(2)}$, y como cualquier otro mito, éste se presenta ante nuestros ojos como un ser vivo, que nace, crece y fructifica, que en el transcurso de los siglos sufre modificaciones desde su versión original, y que es alterado, ampliado y reducido, no sólo en cuestiones de detalle, sino en elementos esenciales ${ }^{(3)}$. La historia de Medea se inicia en la Cólquide donde, según la tradición más antigua, nace de Eetes, hijo de Helio, y de la Oceánide Idía, cuyo nombre, ("la que sabe"), la coloca entre las Oceánides que tienen cualidades intelectuales ${ }^{(4)}$.

(2) Las fuentes fundamentales para la leyenda de Jasón y Medea son, en época arcaica: la Teogonia de Hesíodo y otras obras épicas como las Naupactias y las Corintiacas de Eumelo. En época clásica, Píndaro y Eurípides van a tratar la leyenda desde perspectivas muy diferentes: el primero compone en el 462 a.C. la Pitica IV siguiendo una tradición beocia vinculada a Hesiodo y el segundo, la tragedia que lleva por título Medea, representada en el 431 a.C. que se refiere a una tradición corintia. Ambas narraciones abordan episodios diferentes de la historia de Jasón: Píndaro habla de la expedición y su triunfo, mientras el dramaturgo del declive trágico de sus protagonistas. De todos modos, hay que apuntar el hecho de que entre los trágicos el tema gozó de gran predicamento, al igual que en el arte, puesto que tomaron bastantes motivos de la leyenda para los argumentos de sus piezas y sabemos que varias tragedias perdidas tuvieron como título Medea, Ango, Frixo, las Peliadas, Fineo, las Lemnias, etc. Para encontrar una versión completa de la leyenda, la única que nos ha llegado, tenemos que trasladarnos a la época helenística. Se localiza en el poema épico que lleva el nombre de Las Argonduticas, escrito por un erudito poeta y anticuario, Apolonio de Rodas, que en el siglo III a.C. quiso competir con el viejo Homero.

(3) L. Edmunds ("Introduction: the Practice of Greek Mythology", en L. Edmund (ed.), Approaches to Greek Myth, Baltimore-London, 1990,15) define el mito como "a set of multiforms or variants of the same story, which exists either as written texts, prose or verse, or in oral form, or in both griten and oral form, or in vase painting or plastic art web or independently", es decir, como un conjunto de formas múltiples o variantes de una misma historia que existe en soporte escrito, oral y en las artes plásticas, independientemente o a la vez. Efectivamente, lo característico de los mitos son sus diferentes versiones, muchas veces contradictorias, que a modo de estratos se han ido superponiendo unas sobre otras y además armonizándose, adaptándose y conformándose entre sí, y esto se aprecia con toda nitidez en el leyenda de Medea. Cf. A. López Eire, "El mito de "la otra vida y la justicia cósmica", en S. López Moreda (ed.), Ideas. Contemponaneidad de los mitos clásicos, Madrid, 2002, 181-185.

(4) Según Hesiodo (Th. 958-960) la genealogía de Medea entroncaría con el Títán Hiperión:

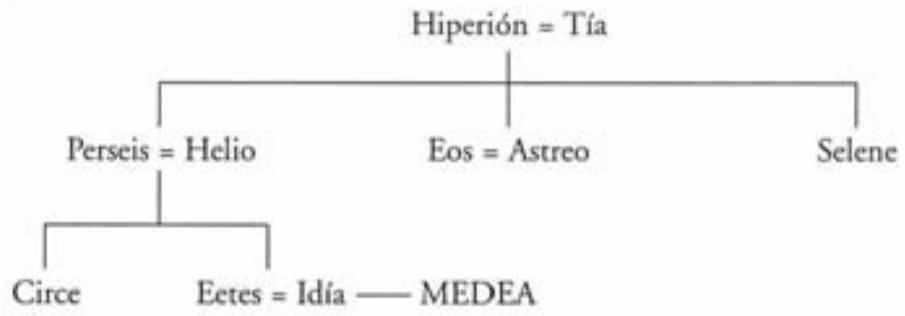


Su propio nombre entronca con la raíz - med, del mismo modo que el ver-

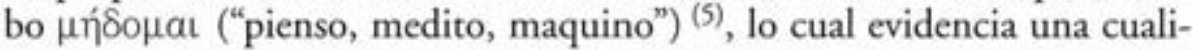
dad fundamental de Medea, la metis, que se manifiesta principalmente en el campo de la magia que usa filtros obtenidos de las hierbas ${ }^{(6)}$. Bajo este aspecto Medea es afín a su tía Circe, por eso no nos extraña que sea calificada de "engañosa" (dolóessa) o rica en hechizos (polyphármakos), los mismos epítetos con que Homero suele definir a su tía, y que Eurípides y Apolonio nos la presenten como una mujer profundamente versada en magia.

Cuando Jasón llega a la Cólquide en busca del vellocino de oro, Medea se convierte en un elemento esencial de su vida, entrando a formar parte de la leyenda de los Argonautas ${ }^{(7)}$. Jasón expone inmediatamente a Eetes el encargo que le confiara Pelias, el tío que había usurpado a su padre Esón el trono. El rey no se niega a entregarle el vellocino pero pone como condición la superación de una serie de pruebas: uncir dos enormes toros de bronce que arrojan llamas por sus fauces, labrar con ellos la tierra de Ares, sembrar dientes de dragón y aniquilar después a los guerreros que nazcan de tal simiente ${ }^{(8)}$. Dubitativo ante tal empresa pide ayuda a Medea, la hija de Eetes, que enamorada locamente de él no duda en prestársela utilizando sus dotes mágicas, convirtiéndose, así, no en mera auxiliar del héroe, sino en la auténtica protagonista de la acción, hasta tal punto que a medida que su aspecto de maga se va revelando, el papel del héroe se va empequeñeciendo. Jasón supera las pruebas gracias al ungüiento mágico que le propor-

Dioniso Escitobraquión (s. II a.C.) nos aporta otra genealogia de la raza de Helio, en la cual Medea y Circe serian hijas de Eetes y de Hécate (FGrH 32F14= D.S. IV 45, 1-3). Para un análisis de los testimonios literarios que ven a Medea como una diosa of. Moreau, 1994, 101-102, que cree que su divinidad aparece confirmada en la Teogonia de Hesíodo cuando es incluida en una sección dedicada a las "diosas que uniéndose en el lecho a hombres mortales, siendo inmortales, generaron hijos semejantes a los dioses" (vv, 967-968).

(5) Cf. P. Chantraine, Dictionnaire étymologique de la langue grecque, Paris, 1968-1980

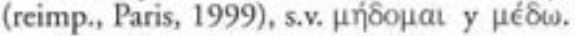

(6) Iriarte (1989, 264-265) dice: "al igual que el arte de mentir, la destreza en el dominio de los fármacos y venenos requiere este tipo de inteligencia, a la vez retorcida y previsora, que los griegos denominan metis". De todos modos, la predisposición de las mujeres hacia la magia es un topos literario, frecuente en los textos antiguos: Ar. Nu. 749, Democr. 793, 28; Luc. Ddeor. XX, 10; Bis Acc. 21.

(7) Los elementos esenciales de la estancia de Jasón en la Cólquide están perfectamente desarrollados con anterioridad a Apolonio de Rodas. Aparecen en Eumelo de Corinto, las Naupactiats (fr. 4, 6-8 Bernabé), en Píndaro (P. IV 211-251), Sófocles (fr. 312-332 y 491-493 Nauck 2) y Ferecides de Atenas ( FGrH 3F22, 30-32, 100, 112). Cf. F. Vian, Apollonios de Rhodes. Angonautiques, I, Paris, Les Belles Lettres, 1976, XXVI-XXIX; Moreau, 1994, 67-68, hace un minucioso relato del mito.

(8) A.R. III 230-233; Apollod. Bibl. I 9, 23. 
ciona Medea, que tiene la propiedad de hacerle invulnerable e invencible, aunque sólo por un día, y cuando Eetes medita su muerte, de nuevo la heroína con su poder hipnótico adormece al dragón eternamente insomne que custodiaba el vellocino para que el héroe pueda apoderarse de él ${ }^{(9)}$.

Con la ayuda prestada a Jasón, Medea ha trasgredido los lazos familiares y tiene que huir con el héroe; es lo que se conoce como el regreso de los Argonautas a Yolco (Tesalia). En el trayecto contraen matrimonio y la heroína, una vez más, va a hacer gala de sus poderes mágicos en la muerte de su hermano Apsirto y la del gigante Talo. El relato más antiguo de su estancia en Yolco, nos la proporciona la Teogonía de Hesíodo ${ }^{(10)}$ que nos muestra a una pareja feliz después de haber puesto fin a sus aventuras y azarosas andanzas ${ }^{(11)}$. Sin embargo, la épica posthomérica (Nóstoi) relata interesantes sucesos en los que se ven implicados Jasón y Medea: el rejuvenecimiento de Esón, padre de Jasón, hirviéndolo en un caldero y la muerte del rey de Yolco, Pelias, a manos de sus propias hijas, en venganza por haber enviado a su marido en busca del vellocino tratando de que sucumbiera. En la versión más conocida persuadió a sus hijas (las Pelíades), de que poseía un remedio secreto capaz de rejuvenecer a su padre, haciendo una demostración ante ellas con un viejo carnero al que, después de cocerlo en un caldero, convirtió en corderillo ${ }^{(12)}$. Convencidas ante esta

(9) En este caso el hechizo se mezcla con otro ingrediente imprescindible en la magia, el encantamiento (epodós): las palabras que a menudo repiten aquello que se quiere lograr, produciéndose inmediatamente. Cf. Vega Vega 2002. La ayuda estaba condicionada a que el héroe cumpliera las promesas que le había hecho de casarse con ella. En la versión que acabó imponiéndose Jasón consigue su objetivo gracias a Medea. Sin embargo, Píndaro $(P$ IV) convierte al héroe en el verdadero artífice del episodio, êl es quien mata al dragón para conseguir al vellocino, $\mathrm{y}$ distintas representaciones iconográficas de la primera mitad del siglo $\mathrm{V}$ a.C., nos dan a conocer una versión diferente: el combate entre Jasón y el dragón, la deglución de aquél por parte del dragón y su posterior regurgitación gracias a la protección de Atenea. $C f$. Moreau, 1994, 31-36 y para las representaciones iconográficas puede consultarse el Lexicon Iconographicum Mithologiae Classicae, vol. VI, 1992, 386-398, s.u "Medeia"; vol. V, 1990, 629-638, s.u "Iason", y una buena sintesis de las representaciones figuradas del mito puede seguirse en T.H. Carpenter, Arte y mito en la Antigua Grecia, trad. esp., Barcelona, 2000, 183 194 y en R. Buxton, Todos los dioses de Grecia, trad. esp., Madrid, 2004, 108-113.

(10) vv. 992-1002.

(11) Hesíodo habla de Jasón y de Medea como de un matrimonio feliz, con un hijo, Medeo. Quizás su relato dependa de una tradición que conclúa con el regreso del héroe y los funerales de Pelias. En este sentido, testimonios antiguos, que se remontan a los siglos VII y VI a.C. describen los Juegos Fúnebres organizados en honor de Pelias: Estesícoro (fr. 178-180 PMG) y Pausanias (V 17, 9-11) mencionan a los participantes, y Simónides (fr. 564 PMG) declara que Homero y Estesícoro cantaron a estos juegos, en los que participaron todos los Argonautas incluido Jasón, y cuya descripción completa nos la ofrece Higinio, en la Fábula 273.

(12) Apollod. Bibl. I 9, 27 y Paus. VIII 11, 2 cuentan esta prueba de rejuvenecimiento con el carnero. 
maravilla, las hijas de Pelias le ruegan que haga lo mismo con su padre y caen, así, en la trampa que Medea les había tendido: matan a su padre, lo hacen pedazos y lo cuecen ${ }^{(13)}$.

Sabemos que Medea, como su tía Circe, tiene poder para alterar la naturaleza humana, concretamente para rejuvenecer y que testimonios del siglo VI a.C. hablan de la aplicación de esta capacidad también a Jasón ${ }^{(14)}$. Pero de esta faceta quien mejor da testimonio es Ovidio en sus Metamorfosis (VII 159-296). El poeta se centra en la magia de Medea, $\mathrm{y}$ a través de los más mínimos detalles de la ceremonia nos conduce hacia una magia claramente negativa en su desarrollo y sus fines. Es el propio Jasón el que pide a Medea que use sus conocimientos mágicos para darle unos años de su vida a su padre Esón. Medea accede a rejuvenecerle y amparándose en el lado oscuro del registro mágico, dominado por la noche y por la muerte, invoca a Hécate y a la Juventud y a otros dioses infernales, Hades y Perséfone. A continuación mezcla en un caldero raíces y otros elementos, todos ellos vinculados con la fuerza de la vida que identifica a la juventud. Después vierte la poción en las venas de Esón a través de un corte en el cuello, e inmediatamente recupera el aspecto de cuarenta años atrás. Cuando las hijas de Pelias piden que haga lo mismo con su padre, el proceso mágico comienza de nuevo, pero cuando las Pelíades abren las venas de su padre para rellenarlas con el líquido vivificador, lo único que fluyó fue su sangre y con ella la vida (VII 297-349) ${ }^{(15)}$. Ovidio ha cambiado el motivo tradicional de la cocción en el caldero que aparece en las fuentes griegas por la aplicación directa de los phármaka ${ }^{(16)}$.

(13) La tragedia más antigua de Eurípides, las Peliadas, representada en el 455 a.C., trataba sobre este tema. Cf. P.J. Sijpesteijn, "The Rejuvenation Cure of Pelias", ZPE 9, 1972, 104-110; Moreau, 1994, 48, n. 89; D. Pralon "Les Péliades d'Euripide", en Médie et la violence, 69-83.

(14) Eurípides en el argumento de su Medea cita en este sentido a Simónides (fr. 548 $P M G$ ) y a Ferecides ( $F G r H 3$ F113) como fuentes: "Ferecides $y$ Simónides afirman que Medea, tras cocer a Jasón, lo rejuveneció". Licofrón (La Alejandra, v. 1315) lo que hace posteriormente es situar la escena en un lugar: la Cólquide, $y$ un momento concreto: entre las pruebas ordenadas por Eetes a Jasón y la toma del vellocino. Cf. A.P. XIV, 59 y XV, 26 y los comentarios al respecto de Moreau, 1994, 70, n. 48. Vian $(1982,283)$ sugiere con prudencia que se hallan huellas de este motivo arcaico en la doble transfiguración de Jasón en el canto III de las Argonduticas de Apolonio, gracias a Hera (vv. 919-925) y a Medea (vv. 1256-1260).

(15) Existen testimonios latinos que apoyan el auténtico rejuvenecimiento de Pelias, como por ejemplo Plauto (Pseud. 868-871) que atribuye el rejuvenecimiento a las drogas (venenum) de Medea, lo mismo que Varrón en sus Sdtinas Menipeas (fr. 285 Bücheler) o Cicerón en Catón el Viejo (383). Sin embargo, creemos que deben ser tomadas con precaución, ya que pueden estar en relación con una deformación cómica del mito.

(16) En en siglo VII a.C., en los Nóstoi o Regresos, ya existe constancia del rejuvenecimiento de Esón: "Al momento convirtió a Esón en un amable muchacho en la flor de la 
Tras este triste suceso se refugian en Corinto. Distintas versiones épicas refieren y justifican la presencia de Jasón y Medea en este lugar y cómo allí encontraron la muerte los infelices hijos de esta pareja a manos de los corintios, discrepando de la versión creada por Eurípides, que hacía de la madre la inmoladora de sus propios hijos. Al parecer aquí viven ambos en armonía hasta que Creonte, rey de Corinto, quiere casar a su hija Glauce ${ }^{(17)}$ con el expedicionario argonauta. Esto le obliga a decretar el destierro inmediato de Medea, pero ésta lo consigue demorar para llevar a cabo su propia venganza. Impregnó de veneno un vestido, adornos y joyas que, portados por sus propios hijos, envió en calidad de presentes. Glauce nada más ataviarse con estos enseres comenzó a arder envuelta en un fuego devorador que se extendió también a su padre, que había acudido en su ayuda. Mientras estos hechos ocurrían, Medea daba muerte a sus hijos con sus propias manos y acto seguido escapaba a Atenas volando en un carro tirado por caballos alados que había recibido como regalo de su abuelo, Helio ${ }^{(18)}$.

\section{GÉNESIS DE LA EXÉGESIS ALEGÓRICA}

El término à $\lambda \lambda \eta \gamma o \rho i ́ a$, literalmente "decir otra cosa" traduce una idea más antigua que se expresa por la palabra úmóvola "significación oculta,

juventud, después de borrar la vejez con sus sabios conocimientos, cociendo muchos brebajes en dorados calderos" (FEG 7 Bernabé). Los testimonios sobre la muerte de Pelias son antiguos: Ferecides alude al fatidico final de Pelias (FHGr 3F105), y Píndaro (P. IV, 250) llama de manera contundente a Medea, "la asesina de Pelias". Otras fuentes griegas nos proporcionan relatos más detallados como Diodoro Sículo (IV, 51), Apolodoro (I 9, 27) o Pausanias (VIII 11,2), y desde el último cuarto del siglo VI a.C. queda reflejado este episodio en la pintura vascular. $C f$. LIMC.

(17) El nombre de Glauce lo encontramos en los dos argumentos de la Medea de Euripides, pero lo omite a lo largo de la tragedia. Cf. Apollod. Bibl. 1 9, 28; Paus. II 3, 6; Luc. De Sal. 42; Hygin. Fab. 25. En otros textos aparece con el nombre de Creusa: Ov. Her. XII 53; Sen. Med. 817, 922.

(18) La versión de Eurípides es el resultado de un proceso iniciado varios siglos antes con las Corintiacas de Eumelo, que es el primero en situar a Medea en la genealogia corintia, de donde su padre Eetes había emigrado a la Cólquide, y tras una ausencia de cuatro regentes, la familia de Helio volvía al fin a recuperar el trono de la mano de Medea. También nos ofrece la versión más antigua conservada de la muerte de los hijos de la heroína: Medea mata involuntariamente a sus hijos en un rito mágico-religioso cuando esperaba hacerlos inmortales (FEG 3 Bernabé=3A Davies= Paus. II 3, 10-11). Desde esta época tan temprana (mitad s. VIII a.C.-mitad s. VII a.C.) se tiene conciencia de que en Corinto tiene lugar el fatal desenlace de los hijos de Medea, rindiéndole posteriormente culto (Paus. II 3, 6-7; Schol. Pi. O. XIII 74). Un siglo después de Eumelo, otro épico arcaico, Creófilo de Samos, nos cuenta que murieron lapidados por los corintios furiosos por la muerte de su rey y propagan el rumor de que habían perecido a manos de Medea (Schol. E. Med. 264= FEG9 Bernabé= FHGr 3F417). Cf. D.L. Page, Euripides' Medea, Oxford, 1964, XX-XXIX; W. Burkert, "Greek Tragedy and Sacrificial Ritual", GRBS 7, 1966, 87-121; Moreau, 1994, 49-58. 
sentido sobrentendido" (19). Un pasaje de Plutarco del opúsculo De au-

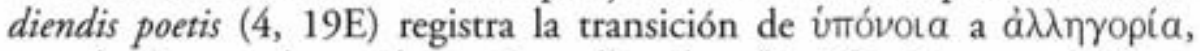
cuando dice que lo que los antiguos llamaban "significaciones ocultas", en

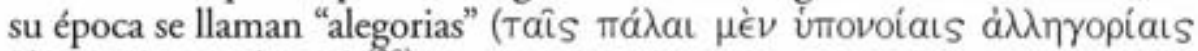

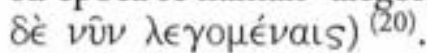

Si à $\lambda \lambda \eta \gamma o p i ́ a$ es "otro hablar", estamos ante una expresión figurada, cifrada, metafórica, cuya definición precisa la aporta Quintiliano cuando dice: allegoria, quam inuersionem interpretantur, aut aliud uerbis, aliud sensu ostendit, aut etiam interim contrarium ${ }^{(21)}$, que no hace más que recoger las definiciones de aquellos autores griegos que habían practicado la exégesis alegórica y que entendían bajo este vocablo una figura retórica que consistía en decir una cosa para hacer comprender otra; es decir, una palabra de significado oculto considerado el verdadero ${ }^{(22)}$.

Aunque el término es relativamente reciente en la lengua griega, la interpretación alegórica aparece muchos siglos antes. Sabemos que a finales del siglo VI a.C. se desarrolla una vigorosa oposición a la teología homérica acusada de dar a los dioses una representación inmoral. Es en este momento, cuando aparecen los primeros ensayos de interpretación alegórica. Pitágoras favoreció el advenimiento de la alegoría por el carácter secreto con que quiso envolver su mensaje y lo mismo ocurre con Heráclito y su forma enigmática de expresarse. Tanto uno como otro habían preparado la transición a la exégesis alegórica homérica. El alegorismo surge, entonces, como un modo de rehabilitar el mito ante los ataques de la explicación racional, que los condenaba como no veraces, como "ficciones de los antiguos" plásmata tôn protéron, empleando la expresión de Jenófanes de

(19) Proclo en su Teologia Platónica $(1,4)$ dirá: "Se hace de los fenómenos físicos el ob-

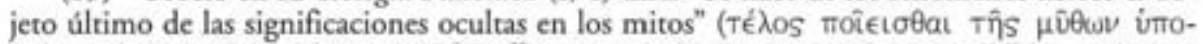

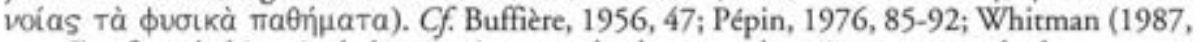
app. I), ofrece la historia de los términos empleados para alegoria, acompañada de una magnifica bibliografia; D.C. Feency, The Gods in Epic: Poets and Critics of the Classical Tradition, Oxford, 1991, 10; García Gual, 1992, 165-172; Ford, 2002, 72-76.

(20) Plutarco está disertando sobre los mitos que proporcionan otras enseñanzas a partir de sus acciones, como se cuenta que dijo Eurípides a los que criticaban su Ixión. Manifiesta que en Homero tal clase de enserianza se silencia, pero tiene una consideración útil a propósito de los mitos especialmente desacreditados, a los que algunos fuerzan y retuercen "con los llamados antiguamente significaciones ocultas y ahora alegorias". Al mismo tiempo en su tra-

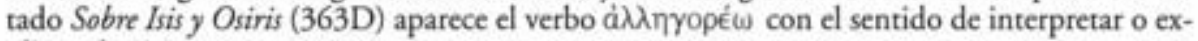
plicar alegóricamente.

(21) Inst. Onat. 8,6.44

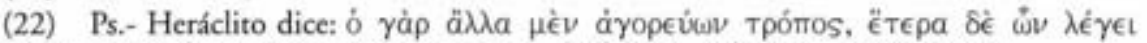

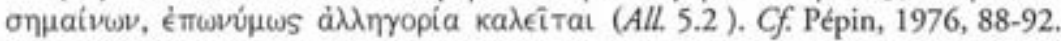


Colofón ${ }^{(23)}$. Por lo tanto, la teoría alegórica es un intento por salvaguardar la lección verídica de los mitos, sólo en apariencia escandalosos; es una manera de justificar la sabiduría del poeta alegando que se expresaba de un modo crítico, mediante un código poético. Con este código el poeta alude y revela verdades profundas ocultas tras un velo de metáforas, tras un ropaje embellecido por imágenes plásticas, que hay que interpretar y descifrar. Sus defensores aceptan que los mitos se expresan en un lenguaje propio, secundario y poético, que hay que traducir al código del lógos para comprenderlos en toda su extensión, profundidad y valor.

El primer autor en practicar la exégesis alegórica fue Teágenes de $\mathrm{Re}$ gio ${ }^{(24)}$, un comentarista de Homero, que vivió en el siglo VI a.C., y cuya doctrina aparece recogida en un escolio al verso 67 del canto XX de la Iliada, conservado por Porfirio:

La enseñanza acerca de los dioses generalmente roza lo violento y aun lo inmoral. Pues ya él [Porfirio] seńala que los mitos de los dioses son escandalosos. Frente a tal juicio, algunos buscan tras la apariencia de su figura verbal una solución a la dificultad, en la creencia de que todo está dicho alegóricamente de la naturaleza de los elementos; asi sería, por ejemplo, cuando se habla de los encuentros hostiles de los dioses. Sefíalan que también lo seco combate contra lo húmedo y lo cálido con lo frío, y lo ligero contra lo pesado. También el agua tiene la facultad de apagar el fuego, y el fuego la de secar el agua. Y así subyace, entre los varios elementos de los que se compone el universo mundo, una oposición, y en parte subyace ésta también al proceso de su destrucción. Pero el conjunto permanece en la eternidad. Así que el poeta [Homero] permite que tengan lugar las batallas [entre dioses] y nombra al fuego Apolo y Helios, y también Hefesto; $y$ al agua Poseidón y Escamandro; a la luna Ártemis; al aire Hera, etc. De manera parecida da él, por otro lado, nombres de dioses a las facultades y propiedades espirituales; así dice en lugar de la inteligencia Atenea, en vez de sinrazón Ares, en vez de pasión Afrodita, en lugar de astucia Hermes, etc. Este modo de explicación [del poema homérico] es muy antiguo, comenzó a partir de Teágenes de Regio, que fue el primero en escribir así de Homero" (Schol. Hom. B, Il. XX, 67= Porphy. I, 240, 14) ${ }^{(25)}$.

(23) Frs. 15-16 DK. Para ver un resumen de los diversos tipos de interpretación de los mitos a partir de Jenófanes of. L. Brison, Introduction à la philosophie du mythe. Sauver le mythe, Paris, 1996.

(24) Según nos informa Taciano en sus Discursos a los Griegos (31) cuando dice: "Sobre la poesía de Homero, ... las primeras interpretaciones son debidas a Teágenes de Regio, contemporáneo de Cambises (529-522 a.C.), a Estesímbroto de Tasos, a Antímaco de Colofón, a Heródoto de Halicarnaso y a Dionisio de Olinto". Cf. E. Ramos Jurado, "Un ejemplo de exégesis alegórica, la Teomaquia homérica de Teágenes de Regio", en J.A. López Férez (ed.), Desde los poemas homéricos hasta la prosa griega del siglo IV d.C., Madrid, 1999, 45-59.

(25) Seguimos la traducción de García Gual, 1992, 196-197. 
La exégesis alegórica gozó de un enorme éxito en el mundo antiguo y ha perdurado en distintas épocas, aunque con algunos matices nuevos. Obtuvo una gran aceptación entre los filósofos. Hacia la mitad del siglo $\mathrm{V}$ a.C. va a ser reconducida por Anaxágoras y sus discípulos, y a finales de siglo será Demócrito el que practique la alegoría física. Es adoptada por algunos sofistas, como Pródico de Ceos ${ }^{(26)}$, los estoicos se sirvieron de ella contra los escépticos y los epicúreos, en un intento de rescatar la doctrina religiosa de los mitos venerables, y los neoplatónicos hicieron algo parecido frente a los cristianos que no querían negar la existencia de los dioses paganos, sino ante todo destacar su inmoralidad escandalosa. Más tarde los gnósticos recurrieron a la hermenéutica alegórica para expresar una concepción semifilosófica del universo, envolviendo sus doctrinas en relatos metafóricos y fantásticos, al modo de los antiguos mitos ${ }^{(27)}$.

Ante autores tan diversos y corrientes tan diferenciadas surge la cuestión de cómo se enfrentaron a la interpretación alegórica. Cada uno de ellos cultivó diferentes tipos de alegoría. Los procedimientos de la interpretación alegórica son diversos, como lo demuestran las múltiples referencias dispersas a través de toda la literatura griega, así como los dos tratados alegóricos que han llegado hasta nosotros: las Alegorias de Homero atribuidas a un tal Heráclito, y el Antro de las Ninfas del filósofo neoplatónico Porfirio. Podemos distinguir, siguiendo a F. Buffière ${ }^{(28)}$ entre las lecturas que transforman los mitos en lecciones de moral y las que descifran en ellos "los misterios del mundo visible"; es decir, existe un alegorismo físico y otro espiritual, según se encuentren tras los mitos alusiones a fuerzas de la naturaleza o a poderes del espíritu. Así, podemos hablar de tres tipos fundamentales de exégesis alegórica: física, que ve en los dioses y en los héroes una representación de los fenómenos de la naturaleza; moral, según la cual dioses y héroes representan virtudes o vicios; y mística o teológica, que hace referencia a las disposiciones del alma ${ }^{(29)}$. A éstas debemos ańadir el alegorismo de carácter histórico que trata de explicar la

(26) Sugiere que los hombres primitivos habian dado nombre de dioses a las cosas que les eran útiles: al pan, Deméter, al vino, Dioniso, al fuego, Hefesto, etc. (fr. 5 DK).

(27) Cf. Pépin, 1976, 93-108; S. Saïd, "Las lecturas alegóricas", en Introducción a la mitologia griega, trad. esp., Madrid, 1999, 58-61.

(28) 1956 (1973) y Héraclite. Allegories d'Homère, Paris, 1962. Señala estos tipos de exégesis alegórica de los mitos de Homero siguiendo a Olimpiodoro.

(29) La física es característica de los estoicos; la histórica, de los peripatéticos; la moral, de los pitagóricos y la mística, la más compleja, la desarrollan, fundamentalmente, los neopitagóricos y neoplatónicos. 
mitología como un reflejo de la realidad y supone que los mitos tienen una verdad histórica disfrazada ${ }^{(30)}$.

Los cuatro tipos serán aplicados para explicar determinados episodios de la leyenda de Medea, pero fundamentalmente el de carácter físico-moral y en épocas muy avanzadas, siglo XVII, aparecerá la alegoría eucarísti$\mathrm{ca}$, partiendo de la idea de que su leyenda cuenta en su figurado y dramático lenguaje los conflictos, temores y esperanzas de su alma.

En un estadio antiguo, Medea fue una maga benefactora, favoreciendo el éxito de la expedición de los Argonautas; después, paulatinamente, comienza a sufrir una evolución y se transforma en hechicera maléfica. De esta forma, el conjunto de la leyenda de Medea nos presenta dos facetas consecutivas y a la vez contrapuestas: de heroína generosa y benefactora pasa a monstruo sanguinario y malévolo. Como es lógico, este aspecto negativo desarrollado como madre, hermana y esposa es el que debe desplegar una sutil hermenéutica, es al que hay que buscarle un sentido simbólico, es el que necesita ser leído como una imagen en clave de una sentencia moral; y será el método alegórico el que permite descubrir tras su escandalosa apariencia un mensaje de mayor alcance. Tras estas consideraciones, vamos a comenzar a analizar las diferentes lecturas de Medea a la luz del alegorismo siguiendo un orden cronológico y resaltando de cada etapa sólo las interpretaciones más llamativas.

\section{LECTURAS ALEGÓRICO-RACIONALISTAS DE LA LEYENDA DE MEDEA}

3.1. En el ámbito clásico griego fue significativa la aportación de la escuela cínica que hacía héroes y heroínas cínicas a personajes míticos de la talla de Heracles, Ulises, Medea o Circe. Especial atención dedicaron a la exégesis de Medea, presentándola como una sabia benefactora y un testigo de la moral que sus miembros practicaban. El principal artífice fue Diógenes el Cínico o de Sínope, discípulo sobresaliente de Antístenes, contemporáneo de Platón. Sigue la alegoría moralizante de su maestro y la aplica ampliamente a Medea, concretamente al episodio del rejuveneci-

(30) Desde el siglo VI a.C. Hecateo de Mileto nos ofrece este tipo de interpretación. $C f$. Decharme, 1904, 393-397 y Buffière, 1956, 228-231. Su principal artífice fue Evémero de Mesene (s. IV a.C.), según el cual los dioses míticos no son más que personajes históricos de un pasado mal recordado, magnificados por una tradición fantasiosa (García Gual, 1992, 201; Domínguez Garcia, 1994, 77-127). A esta vía hemenéutica se le ha llamado también realista o verista (Pépin, 1976, 147) y causalista o etiológica (Sanz Morales, 1999, 404). 
miento de Pelias. Gracias a la alegoría, Diógenes encuentra el modo de justificar este asesinato. Lejos de ser Medea una maga homicida, aparece como especialista en herboristería y dietética que sabe aplicar sus conocimientos para proceder al rejuvenecimiento de cualquier individuo. El caldero representa los baños de vapor y los ejercicios de gimnasia, y el placer que ambos causan en los cuerpos debilitados hace que se reconstituyan y vuelvan a su vigor original. Para Diógenes, dirá Estobeo ${ }^{(31)}, \mathrm{Me}-$ dea no es una maga sino una sabia. Haciéndose cargo de hombres, cuya vida fácil ha embrutecido el cuerpo, los transforma en vigorosos y fuertes mediante sesiones de bańos y gimnasia. Por este motivo se ha difundido el rumor $(\delta \delta ́ \xi a v)$ de que Medea rejuvenecía los cuerpos haciéndolos hervir.

Pero la exégesis de algunos alegoristas aboga a resultados de una asombrosa trivialidad. Esto es lo que ocurre, por ejemplo, con Paléfato, un escritor del siglo IV a.C., seguidor de Evémero ${ }^{(32)}$. Escribió un pequeño

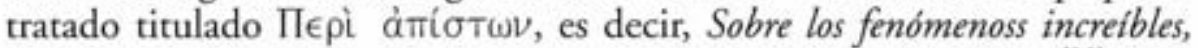
cuyos fragmentos han sido recogidos por los Mithography Graeci ${ }^{(33)}$. Como Evémero, pero sin su racionalismo, busca a través de los relatos míticos clásicos el fondo de verdad positiva. Su método lo aplica a Medea, inspirándose visiblemente en Diógenes ${ }^{(34)}$ :

"Dícese que Medea hervía a los ancianos y los rejuvenecía. Pero no existen pruebas de que haya rejuvenecido a nadie; al que hubiera cocido, sin duda, lo habría matado.

Vino a ocurrir de esta manera. Medea fue quien inventó el tinte ${ }^{(35)}$, tanto rojo como negro. Así pues, hacia que los ancianos canosos parecieran morenos y pelirrojos, pues teñ́a sus cabellos blancos y los transformaba en negros y rojos [...], Medea fue quien descubrió el beneficio que producía a la gente el baño de vapor. Daba baños de vapor a quienes lo deseaban, pero no en público, para que ningún médico lo aprendiera, $y$ al hacerlo tomaba juramento de que no se lo revelaría a nadie. El tratamiento de vapor recibió el

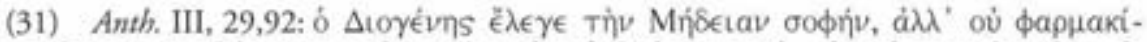

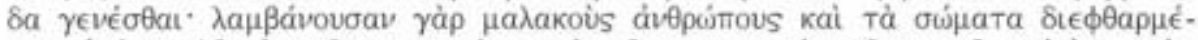

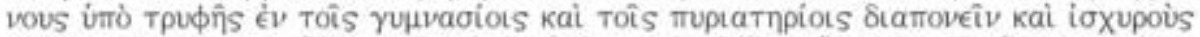

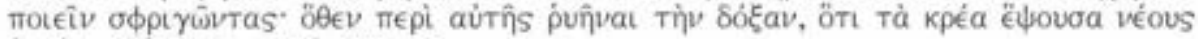
Ė Toít. Cf. Pépin, 1976, 109-111.

(32) Sobre Paléfato, nos aportan unos repertorios bibliográficos muy completos, la edición comentada de Santoni $(2000,45-48)$, y la traducción realizada, para la editorial Akal, por Sanz Morales (2002, 215-217). En sus introducciones tratan de darnos un panorama amplio de la problemática en cuanto al autor, la obra y el tipo de exégesis.

(33) A. Westermann, Mythographoi. Scriptores poeticae historiae graeci, Brunswigae, 1843.

(34) Stob. III $29,92$.

(35) Una atribución similar encontramos en Clemente de Alejandría, Strom. I 16, 76.1. 
nombre de "cocción". Así es cómo la gente quedaba más aliviada y sana merced a los baños de vapor. Por ello, y como veían en su casa las calderas y el fuego, tuvieron la convicción de que hervía a las personas. Pelias, que era anciano y débil, murió al tomar los bafíos de vapor. De ahí el mito" (36) (cap. XIIII).

Paléfato se ajusta en su exposición a un esquema uniforme y claro. Podemos observar dos partes bien diferenciadas: en la primera, nos aporta la versión tradicional del mito ("hervia a los ancianos y los rejuvenecía"), su incredibilidad ("no existen pruebas de que haya rejuvenecido a nadie") y las razones de dicha inverosimilitud ("al que bubiera cocido, sin duda, lo habria matado"). En la segunda, nos da conocer lo que de verdad sucedió, cómo lo cuenta la gente y sus propias conclusiones ${ }^{\text {(37) }}$.

En opinión de M. Sanz Morales ${ }^{(38)}$ en este mito se habría producido un error de percepción, porque un hecho peculiar o raro al que la gente no está habituada, se percibe o aprecia incorrectamente, y a partir de aquí la ingenuidad o la ignorancia lo explican de forma sobrenatural. Este modo de interpretar los mitos, supone que los relatos tradicionales están fundados en errores de transmisión y exageraciones disparatadas. En realidad, según Paléfato, Medea no habría sido más que una profesional hábil en saber transformar los cabellos blancos en otro color para dar una apariencia más juvenil a la persona y en saber aplicar la terapia que hoy ofrecen los balnearios, cuyos bańos de vapor reafirman los organismos debilitados. Preocupada por el buen uso de sus inventos, Medea trabaja lejos de los curiosos. Por otro lado, la preparación de los ungüentos y mezclas para sus baños requiere el uso de calderos para hervir. En fin, que a ella no le llegan más que pacientes demasiado agotados, como el infortunado Pelias, que no soportó el tratamiento. De esta triple circunstancia surgió la leyenda de una maga ejecutando a sus enemigos, haciendo hervir sus miembros troceados en un caldero, bajo la idea de rejuvenecerlos. Esta

(36) Seguimos la traducción de Sanz Morales (2002, 254).

(37) Santoni (2000, 13-15) dice que este esquema se puede aplicar a la mayoría de los cuarenta y cinco mitos que relata.

(38) 1999, 412-414 y 2002, 191-212. Sanz Morales distingue tres grupos de mitos: 1). Los mitos que se deben a un error verbal. 2). Los que se deben a un error de percepción. 3). Los que se deben a un error en la narración de un hecho. Con esta sencilla clasificación quiere destacar que los relatos de Paléfato responden a muy pocos patrones y a mecanismos muy sencillos. En cambio, J. Stern (Palaephatos. Пє pl átriotwv. On Unbelieuable, Wauconda [Illinois], 1996, 18) propuso una clasíficación que se ajustaba a cinco tipos: 1. Juegos de palabras onomásticos. 2. Otros juegos de palabras. 3. Expresiones metafóricas mal entendi-

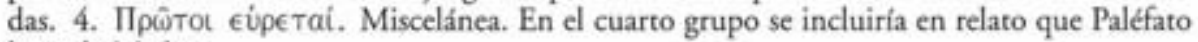
hace de Medea. 
convicción de que las leyendas más increíbles comportaban un punto de partida real emparentaba a Paléfato con Evémero ${ }^{(39)}$.

Entre los discípulos de Paléfato se encontraba Dionisio Escitobraquión ${ }^{(40)}$, que vivió en Alejandría hacia la mitad del siglo II a.C. y en cuya obra se va a inspirar Diodoro de Sicilia para relatar e interpretar la leyenda de Medea, en el libro IV de su Biblioteca Histórica ${ }^{(41)}$. Paléfato y sus discípulos no pueden admitir la inverosimilitud de los mitos, piensan que no pueden ser simples quimeras, que han tenido que nacer de un hecho real $y$, por lo tanto, tienen que buscar sus génesis. Esto es lo que mueve a Diodoro aunque, en opinión de A. Moreau ${ }^{(42)}$, con unos resultados desastrosos: "sa rationalisation est réduction et appauvrissement des mythes, ramenés à un squelette desséchê".

La estancia de Jasón y Medea en la Cólquide es reveladora del racionalismo de Diodoro: suprime la pasión de Medea por el héroe, por lo tanto, ella se limita a colaborar con los Argonautas en un proyecto común que beneficia a ambas partes. El espíritu civilizado de Medea es el que la impulsa a proteger a Jasón contra la costumbre de dar muerte a los extranjeros, impuesta por su padre Eetes (IV 46) ${ }^{(43)}$ :

"....allí encontraron a Medea vagando por la playa. Al enterarse por ella de la costumbre de dar muerte a los extranjeros, agradecieron el espíritu civilizado de la muchacha y, al revelarle su propio proyecto, se enteraron también por ella del peligro en que ella misma se encontraba por voluntad de su padre, a causa del respeto que mostraba a los extranjeros. Así, dado que sus intereses parecían comunes, Medea prometió colaborar con ellos hasta que hubieran llevado a término el trabajo, y Jasón se comprometió bajo juramento a casarse con ella y a tenerla como compañera durante toda su vida".

En su intento de encontrar bajo la ficción poética un fondo de verdad, de realidad histórica, elimina la imagen de maga de Medea durante las pruebas que Jasón tiene que superar en la Cólquide, al remplazar éstas por un enfrentamiento nocturno entre los Colcos y los Argonautas, durante el cual muere Eetes (IV 48, 1-5), y mediante dos términos homónimos reinventa las piezas que le permitan dar la explicación (IV 47, 2-3):

(39) Cf. Pépin, 1976, 181-182.

(40) FGrH $32 \mathrm{~F} 14$.

(41) Las analogías entre ambos son muy precisas. Cf. Moreau, 1994, 224.

(42) $1994,232$.

(43) Para Diodoro de Sicilia seguimos la reciente traducción de J.J. Torres, Gredos, Madrid, 2004. 
“...cuando Eetes reinaba en la Cólquide, se emitió un oráculo según el cual su vida acabaría el día en que desembarcaran unos extranjeros y se llevaran el vellocino de oro. Por esta razón, y por su propia crueldad, Eetes decretó que los extranjeros fueran sacrificados, a fin de que, al esparcirse por doquier la fama del carácter salvaje de los habitantes de la Cólquide, ningún extranjero se atreviera a poner el pie en su país. Asimismo rodeó el santuario con una muralla y puso un gran número de centinelas, escogidos entre los hombres de la Táurica, y por causa de todo ello entre los griegos se forjaron mitos monstruosos al respecto. Se propagó, por ejemplo, el rumor de que en torno al santuario había toros (tâuroi) de aliento de fuego y de que un dragón (drákon) insomne vigilaba el vellocino. La homonimia ha permitido la conversión de los tauros en los poderosos bóvidos y, a partir de la crueldad mostrada en el asesinato de los extranjeros, se ha forjado el mito de los toros de aliento de fuego. De modo semejante, el guarda del santuario, llamado Dracón (Drákon) los poetas lo han transformado en el monstruo y aterrador animal".

La estancia en Yolco de Medea comporta uno de los prodigios más sorprendentes de un mito en el cual no faltan las operaciones mágicas de rejuvenecimiento efectuadas por la heroína a través de muertes, desmembramientos y cocimientos en el caldero. Diodoro suprime estas actuaciones sorprendentes y los hechos suceden gracias a un arsenal de trucos, disfraces, mentiras y fármacos alucinógenos (IV 50-52). Su colaboración en la muerte de Pelias no se fundamentaba en una venganza por haber enviado a Jasón en busca del vellocino, sino en un castigo por haber dado muerte a toda la familia de Jasón. Mientras los Argonautas traman una estrategia para atacar al ejército de Pelias, ella decide ayudarles utilizando sus venenos "de extraordinarios poderes" de los cuales nunca antes se había servido para matar a seres humanos. La demostración que realiza, según la tradición mítica, con el carnero, Diodoro la sustituye por la propia Medea, que es la que se transforma

"Medea preparó una imagen de Ártemis, vacía en su interior, en la que escondió toda clase de drogas; ella misma se untó el pelo con unos tintes poderosos y lo volvió canoso y se cubrió la cara y el cuerpo de arrugas de modo que quienes la viesen pudieran creer que era una auténtica vieja [...] Medea entró en el palacio real, puso a Pelias en un estado de supersticioso temor y con sus prodigios provocó una tal turbación en sus hijas que creyeron que la diosa en persona estaba allí para llevar la felicidad a la casa del rey [...] Medea reveló que la diosa le había ordenado que librara a Pelias de la vejez por medio de ciertos poderes que poséa, que le devolviera un cuerpo completamente joven" (IV 51).

Una vez preparado el escenario ella se lava a fondo todo el cuerpo y borra los efectos de las drogas para causar la mayor expectación posible en $\mathrm{Pe}-$ 
lias y sus hijas. El engaño está servido pero buscando un racionalismo que rechaza lo "maravilloso". Lo mismo sucede con la muerte de Glauce ${ }^{(44)}$ :

\begin{abstract}
"Algunos historiadores dicen que los hijos de Medea llevaron a la desposada regalos untados con venenos y que, cuando los cogí́ y los puso sobre su cuerpo, le sobrevino la desgracia, y que de igual modo murió su padre cuando acudió en su ayuda y tocó su cuerpo". Sin embargo lo que sucedió fue diferente: "ella entró de noche en el palacio real, después de haber cambiado su apariencia por medio de unas drogas, e incendió el edificio aplicando una pequeña raíz que había descubierto su hermana Circe y que tenía la propiedad de que, una vez encendida, era difícil de apagar. De súbito el palacio quedó envuelto en llamas, y Jasón rápidamente saltó al exterior, pero Glauce y Creonte perecieron rodeados por el fuego" (IV 54, 5-7).
\end{abstract}

Siglos después Plutarco menciona otra vez la muerte de Glauce en una interpretación próxima a la de Paléfato y recordando la de Diógenes. Esto es lo que parece desprenderse de un pasaje de la Vida de Alejandro (35, $386 \mathrm{~A}$ ), donde el autor de Queronea narra una curiosa historia en la que un joven ateniense que acompañaba a Alejandro en los baños, se le ocurre con su consentimiento gastarle una broma ("una prueba de líquido") a un joven esclavo de ridículo aspecto. "Si prende en él [el betún de Ecbhatana] y no se apaga, con toda seguridad estaría yo dispuesto, - dice el ateniense- a declarar que su poder es irresistible y espantoso". Entonces, lo unta con este betún y le prende fuego ${ }^{(45)}$.

“...y rápidamente éste comenzó a devorarle por completo y a punto estuvo de morir. Con razón, pues, probablemente, ciertos autores, queriendo resti-

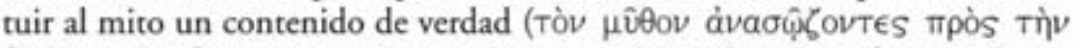

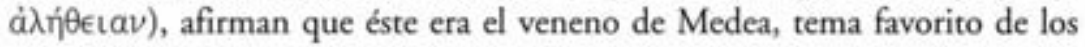
trágicos, con el que ungió la guirnalda y el peplo de los que se habla en la tragedia. Pues el fuego no surgió de ellos mismos ni empezó a arder sin razón; al contrario, al colocar al lado fuego fue cuando se produjo la rápida atracción de la llama y la combustión imperceptible a los sentidos. Efectivamente, los rayos y las emanaciones del fuego, cuando proceden de cierta distancia, no derraman, sobre la mayoría de los cuerpos, más que luz y calor,

(44) Cf. Moreau, 1994, 224-232.

(45) Para Plinio la sustancia utilizada por Medea para acabar con Glauce no había sido una preparación mágica, sino simplemente la naphta. Glauce se habria aproximado a un altar para ofrecer un sacrificio y su corona impregnada en petróleo habría prendido fuego (NH 35 , 178), por lo tanto la explicación racionalista se apoyaba en el hecho que de los antiguos conocían la existencia de petróleo en las regiones próximas a la Cólquide. A esta naphta se la conocía como el "aceite de Medea", ff. D.S. XIX 98; Gal. XII 375; Dioscórides I, 101; Suda, s.v.

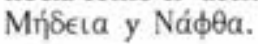


pero en el caso de los que poseen sequedad porosa o humedad grasienta y suficiente, se amontonan y estallan en furiosas llamas, modificando al instante su materia".

Cuando los tratados mitográficos empiezan a hacer su aparición en la época imperial, el tema más escabroso de la leyenda de la maga Medea, el infanticidio, es utilizado por parte del rétor Elio Teón (s. II d.C.), en sus Progymnasmata $(94,12-32){ }^{(46)}$, como ejercicio de retórica, al discutir los argumentos con que puede demostrarse la imposibilidad de un mito o de una narración histórica.

"Nosotros mostraremos la inverosimilitud de la persona, del acto y del lugar de la acción, y al mismo tiempo, de la manera y de la causa de la acción

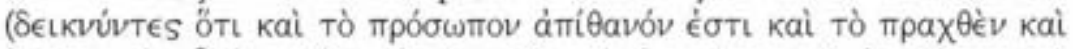

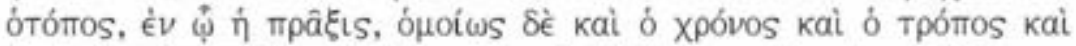

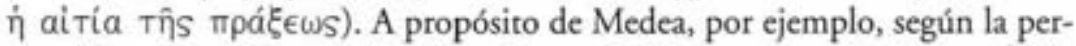

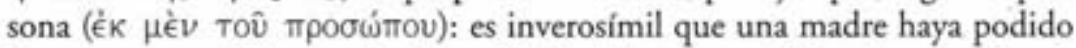

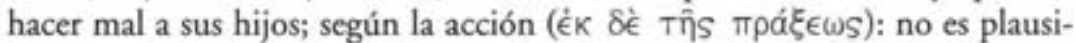

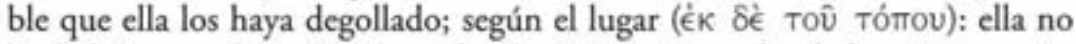
los habría matado en Corinto, donde vivía Jasón, padre de los niños; según

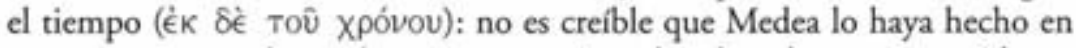
un momento en el que, la mujer extranjera abandonada por su marido, se encontraba en condiciones de inferioridad, mientras que Jasón había acrecentado su poder esposando a Glauce, la hija de Creonte, rey de este país;

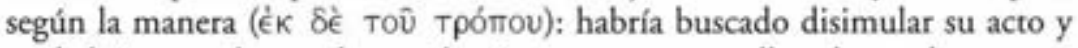
no habría matado con la espada, sino con veneno, ella sobre todo que era

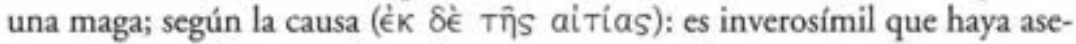
sinado a sus hijos por despecho contra su marido, pues esta desgracia no afectaba solo a Jasón, sino al mismo tiempo a ella misma, sobre todo, en la medida en que la mujer es más vulnerable en los sufrimientos" ${ }^{n}$ (47).

Este alejandrino estima que una madre no podía matar a sus propios hijos. La acción es ya increíble porque Medea no había podido inmolar a sus hijos en la misma ciudad en que vivía su marido y padre de las criatu-

(46) El tratado de Elio Teón (1.a mitad s. II d.C.) propone, a los maestros de retórica, una serie de quince ejercicios gracias a los cuales éstos podrian instruir a los adolescentes en el estudio de la retórica propiamente dicha. $\mathrm{Va}$ a utilizar el mito para ilustrar sus teorias. A propósito del rétor y de su obra es de gran interés la extensa introducción de M. Patillon, Aelius Théon. Progymnasmata, Les Belles Lettres, Paris, 1997, VII-CLVI.

(47) La utilización del mito de Medea, se inserta en la parte de los ejercicios sobre la narración (cap. 5). En el mismo capitulo $(96,11.13)$ al citar diversas historias descritas por Paléfato, recoge dos motivos peculiares de la historia de Medea: su capacidad para teñir el cabello $\mathrm{y}$ hervir en un caldero a quienes quería rejuvenecer. 
ras. Además, la manera misma en que el crimen fue cometido no es creíble: Medea hubiera tratado de ocultar el crimen y, siendo hechicera, habría utilizado el veneno en vez de la espada. Finalmente, la justificación de su gesto es sumamente improbable: la cólera contra su marido no hubiera podido impulsarla a degollar a los hijos de éste, que a la vez eran suyos; por este acto se hubiera hecho más daño así misma, puesto que las mujeres son más sensibles a las emociones que los hombres ${ }^{(48)}$.

3.2. La teoría de que los mitos eran relatos alegóricos, que bajo un disfraz poético y figurado estilo velaban una antigua y perenne sabiduría, encontró en la Edad Media una aceptación extraordinaria. Se sabe que a partir del siglo $\mathrm{V}$ d.C. la mitología se había convertido en tema de desarrollo didáctico. En el umbral del siglo VI d.C. aparecen dos obras alegóricas, una sobre la Biblia, las Moralia de Gregorio Magno, y otra sobre los dioses paganos, en tres libros, las Mythologiae de Fulgencio ${ }^{(49)}$. Efectivamente, al lado de interpretaciones físicas, Fulgencio elabora explicaciones edificantes, buscando siempre el sentido oculto de los mitos. Por lo que respecta a Medea, no se preocupa de hacer una interpretación alegórica de cada uno de los episodios de la leyenda, sino que su exégesis atiende al personaje en sí, como hija de Helio. Venus la impregnó de un amor viciado, por ello recibe el nombre de uno de los sentidos, el oído, carente de visión, porque la voz que hasta ella llega está desprovista de cuerpo visible. Estamos ante una alegoría física pero a la vez moralizante. No le dedica ningún capítulo, pero a ella alude en el capítulo siete del libro II, al relatar la fábula de los amores de Venus con Marte.

[...] Haec itaque quinque Solis filias, id est quinque humanos sensus luci ac ueritati deditos quasi solis fetus hac corruptela fuscatos [amore succendit]. $\mathrm{Ob}$ hac re etiam huiuscemodi nomina quinque ipsis Solis filiabus uoluerunt: primam Pasiphen ut uisum, id est quasi pasinfanon, quod nos Latine omnibus apparentem dicimus -uisus enim reliquos quattuor inscipit sensus, quia et eum qui clamat uidet et palpanda notat et degustata aspicit et odoranda intendit, secundam Medeam quasi auditum hoc est medenidean quod nos Latine nullam

(48) El texto de Teón es tomado casi literalmente por un comentarista anónimo de Aftonio de Antioquia (s. IV d.C.) (28.27-29. 10 Walz II), La historia de Medea aparece recogida por un tal Nicolaos (s. V. d.C.), siguiendo la disposición de los Progymnasmata (I 301-304; 312-314; 400-401 Walz I) y Hermógenes la utiliza también para ilustrar su teoría de la narración (5.2 Rabe).

(49) Sobre esta obra dirá un clérigo del siglo XII, Sigiberto de Gembloux, "el lector se siente casi espantado por la agudeza de un espíritu que traspone filosóficamente todas las fábulas bien al plano de la naturaleza, bien al de la moral". Cf. Seznec, reimp. 1987, 80 . 
uisionem dicimus - uox enim corpore nuda est-, tertis Circe tactui similis $[\ldots]^{(50)}$ (II 7).

"a las cinco hijas del Sol, es decir, los cinco sentidos humanos consagrados a la luz y la verdad, como vástagos del Sol ofuscados por este vicio [los inflamó de amor]. Por esta razón se les pusieron estos nombres a las cinco hijas del Sol: la primera Pasife, como la vista y es así pasifanon — que nosotros en latín decimos la que aparece a todos-, pues la vista ve a los otros cuatro sentidos porque ve al que grita, distingue al que palpa, percibe lo que gusta y observa lo que huele. La segunda Medea, como el oido; esto es medinean, que nosotros en latín decimos "ninguna visión", pues la voz está desnuda de cuerpo; la tercera Circe...."

En la Edad Media está muy arraigado el gusto por cristianizar extrayendo de las fábulas paganas una enseñanza moral. Un método tan habitual que Gregorio de Tours percibió el peligro que entrañaba y pidió volver la vista hacía el Evangelio, aunque estas advertencias no dieron su fruto porque en el siglo VIII, en época carolingia, aparece un poema de Teodulfo (750/60-821), obispo de Orleáns, sobre la manera de entender filosóficamente las fábulas de los poetas. $\mathrm{El}$ autor parte de la idea de que aunque muchas cosas sean frívolas, muchísimas verdades yacen ocultas bajo un falso velo ${ }^{(51)}$. Este será el caso de Medea, a la que dedica una escueta mención, viéndola como la Razón, porque no hace nada sin haber experimentado antes la meditación ${ }^{(52)}$. De este modo la mitología tiende a convertirse en una Philosophia moralis, entreviendo en los personajes míticos y sus historias prefiguraciones de la verdad cristiana ${ }^{(53)}$.

Así, en el siglo XII la tradición alegórica está en todo su esplendor. Entorno al año 1100 aparece el tratado del filósofo Albricus, Liber imaginum deorum, que alcanza altas cotas de difusión. Condensa su material recogido por los gramáticos o los compiladores de los últimos siglos de la Antigüedad y lo enriquece con añadidos de sus predecesores medievales. Sus fuentes principales son las Mitologias de Fulgencio, el Comentario de Ser-

(50) Seguimos la edición de R. Helm, Fabii Planciadis Fulgentii V.C. Mitologiarum Libri Tres, Stuttgart, 1898 (reimp. 1970).

(51) Falsa poetarum stilus, vera sophorum/ falsa horum in verum uertere saepe solent... Los poemas se han conservado en parte gracias a la editio princeps del jesuita Jacques Sirmond (Paris, 1646), pero la edición crítica que hemos manejado es la de E. Dümmler, MGH Poetae I, 1881, 437-581. Cf. F. Brunhölzl, Histoire de la Litténature Latine du Moyen Age, I.2, Louvain-la-Neuve, 1991, 48-57 (trad. de la edic. alemana de 1975).

(52) Cicerón en De Natuma Deorum (III 71) recuerda a Medea y a Atreo como personajes heroicos que meditaban sus crímenes funestos urdiendo un soterrado razonamiento ( $f$. III 66-68).

(53) Cf. Seznec, reimp. 1987, 81. 
vio sobre la Eneida, las Saturnales y el Comentario sobre el Sueño de Escipión de Macrobio ${ }^{(54)}$; las Bodas de Mercurio y Filologia de Marziano Capella, las Etimologías de Isidoro y el Comentario de Remigio de Auxerre sobre Capella. Busca siempre el sentido "oculto" de los mitos, prestándoles alternativamente una significación histórica, física o también moralizante. Por ejemplo, Venus y Marte significan la Voluptuosidad que mancilla la Virtud, y cuando el Sol descubre sus culpables amores, Venus se venga extraviando a las cinco hijas del Sol; es decir, los cinco sentidos: Pasifae, la vista; Medea, el oido; Circe, el tacto; Fedra, el olfato y Dircé, el gusto, equivalencia que ya hemos visto en Fulgencio ${ }^{(55)}$.

A partir del siglo XII en que la alegoría se convierte en el vehículo universal de toda expresión piadosa, la exégesis mitológica bajo esa orientación adquiere asombrosas proporciones y, evidentemente, el mito de Medea se presta bien a este tipo de hermenéutica. Las descripciones provenientes de la tradición edificante de Fulgencio y de Marciano Capella, que van a ser recogidas más tarde en los tratados mitográficos, pasaron también a la literatura. La tradición alegórica la encontramos en Le Roman de la Rose. Con este nombre se designa desde el último cuarto del siglo XIII a una extensa obra de 22.000 versos redactada por Guillaume de Lorris, a quien se deben los 4.000 primeros versos, y por Jean de Meun, al que corresponden los 18.000 restantes ${ }^{(56)}$. Ambos son hombres capaces de abordar este trabajo, porque se aúna el gusto del primero por la alegoría y los importantes conocimientos de mitología del segundo, adquiridos a través de los mitógrafos vaticanos I y II, y un extraordinario interés por descubrir bajo el tejido del mito "une grant partie des secrez de

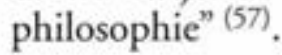

(54) Saturn. I, 12, 21-27 habla de la habilidad de Medea para preparar brebajes a base de hierbas.

(55) Cf. Seznec, reimp. 1987, 144-145. Las deudas directas de la literatura clásica son escasas, si exceptuamos el De natura deorum de Cicerón, al igual que las citas de los poetas, aunque sí parece haber consultado los escolios de Horacio, Estacio, Persio y Lucano.Cf. R. Raschke, De Alberico mythologo, Breslau, 1913, donde el autor hace un minucioso análisis de las fuentes.

(56) Guillaume escribiria los primeros 4.000 versos alrededor del 1225 , mientras que Meun lo haría entre 1268 y 1278, cuando contaba con unos 25 años. Cf. V. Langlois, Origenes et sources du Roman de la Rose, Paris, 1891, 134-137.

(57) Para comprender este tipo de trabajos es de suma ayuda H.R. Jauss, Genèse de la poésie allégorique française au Moyen Age de 1180 à 1240. Heildelberg, 1962 y "La transformation de la forme allégorique entre 1180 et 1240: d'Alain de Lille à Guillaume de Lorris", en Humanisme medieval, 1964, 107-142; M.R. Jung, Études sur le poème alligorique en France au moyen age, Berna 1976 y "Jean de Meun et l'allégorie", Cahiers de l'Association Intern. d" Etudes Françaises 28, 1976, 21-36. 
El tema es de índole amoroso, por ello necesita la presencia de una dama. En contra de lo que se podía esperar el personaje femenino se desdobla en múltiples personificaciones alegóricas, cada una de las cuales representa una actitud, un sentimiento de la amada o un vicio habitual en el mundo de la corte. De este modo, el poeta-enamorado-narrador cuenta sus desdichas amorosas, analizando con detenimiento cada una de las reacciones de la dama, que son expresadas, mediante un recurso que remonta a Prudencio, en plena acción, como partícipes de un combate interior. La alegoría se convierte así en algo más que el hábil movimiento de unas personificaciones, es algo más que una "metáfora prolongada": acaba siendo el único cauce válido para la expresión de unos sentimientos que de otra manera habrían sido descritos con cierta frialdad.

La aparición de la figura de Medea se reserva a la parte elaborada por J. Meun (vv. 13.199-13.252) y la pone en boca de una Vieja que ironiza sobre la relación de Jasón y Medea, insistiendo en los favores que ésta hizo al héroe y cómo le pagó éste, concluyendo su alegato sobre el modo en que debe comportarse cualquier mujer ante los hombres. Sirve esta leyenda para explicitar un modo de conducta, una norma a seguir.

"Y Jasón, ¿qué hizo con Medea, burlada con tal desprecio que el traidor faltó a su palabra después que ella le salvara de la muerte y le librara con su magia sin que él sufriera las heridas ni las llamas de los toros que echaban fuego por sus fauces y pretendian quemarlo o despedazarlo? También embriagó al dragón, de modo que no pudo despertarse, tan profundo era el sueńo que Medea le provocó. Frente a los caballeros del reino, belicosos e insensatos, que pretendían matar a Jasón cuando él arrojara la piedra, ella obró de modo que se atacaron los unos a los otros y se mataron entre ellos. Medea logró que Jasón conquistara el vellocino con sus artificios y sus pócimas. Luego hizo rejuvenecer a Esón para ganarse mejor a Jasón. Ella solo quería que Jasón la amara como antes y que apreciara sus méritos para conservar mejor su fidelidad. Pero él acabó abandonándola, el infame traidor, el tramposo, el desleal, el bribón. Cuando Medea lo supo, ella también estranguló a sus hijos, presa de dolor y de rabia, pues con él los había tenido. Así cometió su locura, olvidando su amor de madre y comportándose peor que una cruel madrastra.

Todos los hombres burlan a las mujeres y se mofan de ellas. Son todos unos libertinos y se ríen de todo. Por eso hay que engañarlos de igual modo, y no atar nunca el corazón a uno solo. La mujer que lo hace es una insensata. Por el contrario, debe tener muchos amigos y obrar de modo que, si puede, guste tanto a todos que los deje en gran tormento. Si ella no posee gracias naturales, que las adquiera, $y$ se comporte con el mayor orgullo ante ellos, que 
así se afanarán más en servirla. Que se esfuerce también en conquistar a aquellos que no buscan su amor..." (58).

Medea una mujer maléfica en otros tiempos es ahora víctima de la traición masculina, que justifica su infanticidio. Este clérigo es hombre capaz de descubrir bajo el mito "una gran parte de los secretos de la filosofía": recupera, así, a Medea y su carácter benefactor, utilizándola como espejo en el que no deben mirarse las mujeres, sino quieren acabar como ella ${ }^{(59)}$.

A partir de esta época comienzan a aparecer escritos alegóricos en toda Europa dado que la mitología se consideraba "un conjunto de preceptos morales ingeniosamente escondidos". Un ejemplo importante en este sentido es el anónimo poema el Ovide moralisé, compuesto en los primeros años del siglo XIV ${ }^{(60)}$. Su autor formula el principio alegórico con toda nitidez. "tout est pour notre enseignement", es decir, todo va dirigido a instruirnos. El mito de Medea lo relata en el libro VII, a lo largo de más de dos mil versos (vv. 1-2170). En ellos el poeta se centra en las hazañas llevadas a cabo por Medea para ayudar a Jasón a conseguir el vellocino de oro y a mantener su amor. Dedica amplio espacio a los episodios del rejuvenecimiento de Esón y Pelias, pero las explicaciones alegóricas difieren en ambos casos. En el primero, equipara la introducción en el agua del individuo con el bautismo en el río Jordán. Quien entra sale renovado, sale rejuvenecido en su fe y a éstos se les puede "llamar niños puros y llenos de inocencia, sin malicia". Esta renovación los hace puros e inocentes. En cambio, la muerte de Pelias, la justifica porque es el Diablo.

A la luz del neoplatonismo, los humanistas descubren en los mitos algo más que rebasa las ideas morales: descubren una doctrina religiosa, una

(58) Seguimos la traducción del Libro de la Rosa de C. Alvar y J. Muela, elaborada para la editorial Siruela, Madrid, 1986, con una interesante introducción y apéndice.

(59) Cf. N. Zingarelli, "L' allegoria del Roman de la Rose", en Studi dedicati a Francesco Torraca, Napoli, 1912, 495-524; C.S. Lewis, The Allegory of Love, Oxford, 1936; A. Vallone, "Personificazione, símbolo, e allegoria del medioevo dinanzi a Dante", Filologia e Letteratura $10.2,1964,189-224$.

(60) El Ovide Moralisé se inserta en la misma tradición moralizante medieval que el Fulgentius metaforalis de J. Ridewal o el Ovidius monalizatus de P. Bersuire. Sobre los dos problemas principales que plantea el poema: autoría y datación exacta, hoy por hoy no se ha llegado a ninguna conclusión satisfactoria. Cf. C. De Boer, Ovide monalisé, Poème du commencement du XIV ${ }^{e}$ siècle, publié d'aprés tous les manuscrits connus, Koninklijke Nederlandse Akademie van Wetenschappen, Verhandelingen Afd. Letterkunde, n.s. XV 1915, XXI 1920, XXX 1931, XXXVII 1936, XLIII 1938 (Amsterdam, 1915-1938); R. Demats, FABULA. Trois études de Mythographie antique et médituale, cap. II: "Les fables antiques dans l'Ovide moralisé", Genève, 1973. También resultan de gran interés dos estudios de M.a Consuelo Álvarez Morán, El conocimiento de la mitologia clasica en los siglos XIV al XVI, Madrid, 1976 y "El Ovide moralisé, moralización medieval de las metamorfosis", CFC 13, 1977, 9-32 (esp. pp. 22-24). 
enseñanza cristina. Esto es lo que encontramos en la obra de Boccaccio, De mulieribus claris (1361-1375). En este tratado dedica el capítulo XVI a relatar la leyenda de Medea. Como vamos a ver en todos estos tratados, existen dos partes: una parte descriptiva, generalmente, breve, en la que el autor traza los rasgos más relevantes de la leyenda y los atributos de cada uno de los dioses y héroes; y una parte moral, la más significativa, en la que cada divinidad o héroe son interpretados en sentido edificante. Por lo que respecta a la leyenda de Medea, la considera objeto de concupiscencia y de carnales apetitos

"...si por fuerza se ha de mirar a otro, deben ser muy refrenados, que no sean disolutos ni deshonestos, pues la naturaleza les puso puertas, no solo para que las cerrasen para el sueńo, sino para resistir lo dañoso. Las cuales si hubiera cerrado la poderosa Medea cuando puso sus ojos de manera desordenada en Jasón, hubiera durado más el poder de su padre y la vida de su hermano y quedara no dañada la honra de su virginidad".

\section{Para Boccaccio, Medea es el Vicio de la carne porque}

“...en viendo a Jasón fue tan esclava de su desorden que se olvidó de sí misma: destruyó a su padre, mató a su hermano y a la postre a sus propios hijos que no quiso perdonar, obedeciendo al príncipe de la muerte y del inferno espantoso, que es Lucifer, con el que para siempre ha de penar al haber absorbido el espíritu maligno con el que se hace llamar bruja".

Interpretación muy diferente nos dispensa Boccaccio en otro de sus tratados De Genealogia deorum gentilium libri, ${ }^{(61)}$ escrito a mediados del siglo XIV. Dedica a la leyenda de Medea dos capítulos del libro XIII: uno muy breve, cap. XXV, centrado en el rejuvenecimiento de Esón. A propósito de lo cual nos aporta una interpretación alegórica de carácter racionalista: dicho rejuvenecimiento se lo proporcionó la alegría inmensa de volver a ver a su hijo después de una expedición tan difícil, de modo que pareció que su edad retrocedió a otra más floreciente.

"Según afirma Ovidio (VII, 285-293), siendo ya anciano Esón fue rejuvenecido por Medea con el poder de las hierbas. Ficción cuyo significado pue-

(61) Cf. la edición elaborada por M.a Consuelo Álvarez y Rosa M.a Iglesias, Genealogia de los dioses paganos, Editora Nacional, Madrid, 1983. Emprendió Boccaccio esta obra a petición del rey de Chipre y le llevó sus últimos veinticinco años de vida. Por sus proporciones supera a las recopilaciones anteriores, aunque recuerda a las grandes enciclopedias medievales por su intento de vincular cada dios o héroe al poderoso fundador de la raza. Cf. C.C. Coulter, The Genealogy of the Gods. Vassar Mediaeval Studies, New Haven, 1923, 317-341. 
de ser el siguiente. A saber que a Esón se le proporcionó una alegría tan grande por el regreso inesperado de su hijo, lleno de gloria, de una expedición tan difícil, que parecía que su edad, que se inclinaba a la muerte, había retrocedido a una edad más floreciente".

En el siguiente capítulo, XXVI, la narración la hace más extensa abarcando todos los episodios del mito. Como en el anterior concluye su exposición con una interpretación alegórica, pero en este caso ésta se centra en la ayuda que le prestó a Jasón para conseguir el vellocino venciendo a los toros que echaban fuego por la boca y la nariz, que por mandato de Eetes debía uncir a un arado, después arar la tierra, sembrar dientes de dragón y matar a los guerreros que naciesen de ellos. Los toros serían los nobles de Colco vencidos por las artimañas de Medea. El dragón vigilante sería el puesto de guardia del reino, cuya muerte, como si se hubiesen sembrado los dientes, traería disensiones que darían lugar a una guerra entre ellos mismos, que duró hasta que se cansaron, momento que aprovechó Jasón para someterles y quitarles el rebaño con el vellón. Como vemos Boccaccio sigue la tradición de la alegoría histórica muy en la línea de Evémero.

"De esta historia hay algunas cosas bajo el velo de la ficción poética que, si podemos, deben ser descubiertas. Así pues, se lee en primer lugar que él domeñó a unos toros que tenían patas de bronce y que soplaban fuegos por sus narices, que yo considero que fueron los nobles del reino de Colcos, de fuerzas insuperables y de espíritu altivo, de los que pienso que fueron vencidos no con la guerra sino con la palabra y con engaños y que a los del pueblo, arrastrados a su parecer y al de Medea, los dispuso para la sedición y, muerto mediante un engaño el dragón siempre vigilante, esto es el puesto al frente de la custodia del reino y a causa de la muerte de éste, como si se hubieran sembrado los dientes, es decir las causas de las disensiones, los Colcos se armaron contra sí mismos y se mantuvieron en guerra hasta que se cansaron, de manera que por último fueron fácilmente sometidos por Jasón y desnudados de sus riquezas y del vellocino de oro, es decir, del rebaño que tenía un vellón de mucho valor".

La Genealogía de los dioses de Boccaccio fue el principal eslabón que vinculó el Renacimiento a la Edad Media, adquiriendo un notable éxito y ejerciendo una extraordinaria influencia en los tiempos venideros, a pesar de que a partir del siglo XV se empiezan a editar los mitógrafos antiguos que la Edad Media había utilizado como fuentes: el Comentario de Servio, Fulgencio, las Historias Increibles de Paléfato, las Alegorias Homéricas de Heráclito, los tratados de Fornuto y Macrobio, y se reeditan constantemente los mitógrafos medievales. 
La erudición completamente impregnada del alegorismo de prestigiosos escritores de la Antigüedad como Diógenes, Plutarco, Cicerón, Apuleyo, Macrobio, Servio, Fulgencio o Juliano, ofrecieron a los renacentistas apoyos sistemáticos para la interpretación alegórica. Los renacentistas acogieron esta teoría con gran entusiasmo. Encajaba admirablemente en algunas tendencias de la época, en la que ese saber por enigmas y por misterios tuvo grandes adeptos. Los jeroglíficos, los emblemas, el universo críptico de la alquimia y la cábala estaban en contacto con ese saber escondido y secreto, tan solo revelado a unos pocos. La alegoría sirve, entonces, para justificar la presencia de múltiples imágenes paganas ${ }^{(62)}$.

En 1419, un sacerdote florentino, Cristoforo de Buondelmonti, de viaje por la isla griega de Andros, compra un manuscrito griego, que resultó ser los Hieroglyphica de Horus Apolo ${ }^{(63)}$. Editado en 1505 incitó a los humanistas a buscar un equivalente moderno a esos criptogramas antiguos. Este equivalente fueron los Emblemata, cuyo prototipo ofreció Alciato en su primer compendio aparecido en $1531^{(64)}$. El emblema es una imagen que esconde un contenido moral, un comentario explicativo que subyace bajo aquella. A los personajes mitológicos les corresponde un amplio espacio en el Emblematum liber de Andrea Alciato ${ }^{(65)}$. Estos cumplen una función: simbolizan un vicio o una virtud, o bien traducen una verdad moral. De este modo, la corriente alegórica de la Edad Media, muy dejos de agotarse, se prolonga y se amplía más, y los dioses y héroes del renacimiento continúan siendo, con mucha frecuencia, figuras didácticas, incluso instrumentos para la edificación de las almas.

Medea ocupa un lugar relevante en tres emblemas, en los que la faceta de madre y de mujer enamorada van a ser representativas. En dos de ellos el autor alude a su comportamiento nefasto como madre, poniéndola como ejemplo de lo que no se debe hacer; mientras que en el tercero representa a una Medea enamorada, pero cuyos filtros de amor se pueden contrarrestar. La larga serie sobre el Vicio de la Perfidia y de la Deslealtad, Alciato lo concluye con el Emblema LIV: ei qui semel sua prodegerit, alie-

(62) Cf. E. Garin, El hombre del Renacimiento, trad. esp., Madrid, 1990, 11-22.

(63) Cf. E. Iversen, The Myth of Egypt and its Hieroglyphs in European Tradition, Copenhague, 1961; A. Rigoni-E. Zanco, Orapollo. I Geroglifici, Milano, 1996. Disponemos de una edición en lengua castellana a cargo de J.M. González de Zírate, Horapolo, Hieroglyphica, Akal, Madrid, 1991.

(64) Para una visión general del tema de la emblemática en España, of. A. Sánchez Pérez, La literatura emblemática española de los siglos XVI y XVII, Madrid, 1977.

(65) La edición espańola de los Emblemas se la debemos a S. Sebastián, que vio la luz en Madrid, en 1985 (editorial Akal). 
na credi non oportere ("que no conviene confiar los bienes ajenos a quien dilapidó los propios"). En él Medea es prototipo de maldad, por ello se amonesta a la necia golondrina que hace su nido en la hornacina de Medea, confiando sus hijos a la mujer que mató a los suyos. El Emblema CXCIII, dedicado al Amor filiorum, amonesta a las madres que no quieren a sus hijos o los matan, como Procne y Medea. Contrapone la figura de Medea a la de la blanca paloma que hace su nido en invierno y llega a despojarse de sus plumas para mantener calientes a sus pichones, un comportamiento de madre muy diferente al que mantuvo la heroína ${ }^{(66)}$.

Finalmente, Alciato en la serie de emblemas dedicados a la Lujuria, después de describir los graves dańos que ésta ocasiona, tratará de contrarrestar sus efectos presentando por una parte el Amuletum Veneris (Emblema 67) y por otra los Inviolabiles telo cupidinis (Emblema 68). En el primero centra su atención en la leyenda de Adonis y Afrodita y en el segundo en Medea y Jasón. En éste describe el remedio que sirvió a Jasón para librarse de Medea representando al pájaro pezpita o aguzanieves, ave de Baco, que tiene el poder de librar al hombre de los hechizos de amor ${ }^{(67)}$.

"Para que no te someta el cruel Amor, ni ninguna mujer devaste tu alma con artes mágicas, te aconsejo que te hagas con una aguzanieves, ave consagrada a Baco, a la que colocarás en cruz en un círculo. La cruz fórmala con la cabeza y la cola y las dos alas desplegadas. Este será tu amuleto contra todo hechizo. Se dice que con tal signo de Venus se libró Jasón de ser dańado por los hechizos de la de Fasis". (68)

La tradición mítica antigua nos dice que una Medea enamorada ayuda a Jasón a superar las pruebas impuestas por su padre al héroe y que el sentimiento que despierta en ella el héroe le provoca una tormentosa va-

(66) Ante diem vernam boreali cana palumbes frigore nidificat, praecoqua et ova fovet: mollius et pulli ut iaceant. Sibi vellicat alas, queis nuda hiberno deficit ipsa gelu. Ecquid Colchi pudet, vel te, Progne improba? Mortem cum tolucris propriae prolis amore subit?. Cf. A.P. IX 95; Plin. X 34, 35 .

(67) Así reza el texto que acompania al emblema: Ne dirus te vincat amor, neu femina mentem diripiat magicis artibus ulla tuam, Bacchica avis praesto tibi motacilla paretur. Quam quadrinadiam cinculi in orbe loces ore crucem et cauda, et geminis ut complices alis, tale amuletum carminis omnis erit. Dicitur hoc Veneris signo Pagasaeus Iason Phasiacis laedi non potuisse dolis. J. Piero Valeriano en su Hieroglyphica, Basilea, 1567, XXV, 52, expone algo semejante en cuanto a la atracción amorosa.

(68) Medea. Fasis es un río de la Cólquide. 
cilación entre la lealtad a su familia y el dejarse arrastrar por la fuerza irresistible del amor, convertirse en una ayudante imprescindible y cumplir las funciones de poderosa maga capaz de ejecutar los más extraordinarios portentos. Sin embargo, la tradición también ha tratado de buscar las causas de su enamoramiento. Para Píndaro ${ }^{(69)}$ la razón estriba en un encantamiento que hizo Jasón, siguiendo las instrucciones de Afrodita, atando un pájaro, el tuercecuello, a una rueda mágica, con lo cual se produjo la paradoja de la hechicera hechizada,

"Pero la señora de las flechas más agudas, en Chipre nacida, unció el variopinto torcecuello a los cuatro radios de una rueda sin escapatoria y desde el Olimpo llevó por vez primera a los hombres el ave enloquecedora, y enseñó al hijo de Esón a ser ducho en letanías de ensalmos, para que arrebatara a Medea el respeto por sus padres y para que su anhelo por la Hélade, la hiciera vibrar abrasada en su corazón, con el azote de la persuasión. Ella, sin vacilar, le indicó cómo superar las pruebas paternas $y$, tras preparar, mezclados con aceite, mágicos antídotos de crueles dolores, dióselos para que se ungiera con ellos. Y hubo mutuo acuerdo en contraer dulce matrimonio".

y precisamente, este motivo es el que recoge el emblema de Alciato aunque con un fin distinto.

3.3. Los mitógrafos renacentistas retoman los viejos procedimientos de la explicación histórica, física y moral, propuestos por la Antigüedad y utilizados durante la Edad Media, considerándolos una parte esencial de su tarea, aunque en ningún momento intentan conciliar las diferentes posturas. Es el caso de Natale Conti, en cuyo tratado mitológico editado en Venecia en $1551^{(70)}$, la interpretación del mito ocupa un espacio desme-

(69) P IV, 213-222. En Apolonio (III 270-300), en cambio, la cuestión está resuelta de manera diferente. El enamoramiento se produce por una intervención directa del mismo Eros, a ruegos de su madre Afrodita, pero el proceso está visto desde el lado puramente humano. Seguimos para Píndaro la traducción de E. Suárez de la Torre, Cátedra, Madrid, 1988.

(70) Se publicó con el título de Mythologiae sive explicationum fabularam libri decem y se reimprimió en diversas ocasiones $(1567,1568$, etc.) hasta 1581 en que va a aparecer en Venecia una nueva edición revisada y ampliada por el autor, que dará lugar a numerosas reimpresiones: 1596, 1609, 1616, etc. En este sentido encontramos abundantes datos en la "Introducción" a la edición española de Rosa M. Iglesias y M.* Consuelo Álvarez, Murcia, 1988, 7-39, e igualmente en la "Introducción" a la edición de la Philosofia Secreta de Pérez de Moya de C. Clavería, Cátedra, Madrid, 1995, 13-39. 
surado ${ }^{(71)}$. Está plenamente persuadido de que la mitología oculta una sabiduría profunda accesible, únicamente, a aquellos que no se quedan en la corteza de las fábulas, es decir, en el sentido literal. Al inicio de su manual expone los principios que van a guiar su obra $(\mathrm{I}, 1)$ :

"Desde la más remota Antigüedad, los pensadores de Egipto, los de Grecia más tarde, disimularon deliberadamente con el velo de los mitos las grandes verdades de la ciencia y de la filosofia, a fin de sustraerlas a las profanaciones del vulgo. Con este propósito inventaron no sólo las historias de los dioses, sino también sus figuras: son ellos los que entregaron el rayo a Júpiter, el tridente a Neptuno, las flechas a Cupido, la antorcha a Vulcano. Más tarde, cuando los sabios pudieron enseñar públicamente, sin rodeos, y sus preceptos aparecieron a plena luz, las fábulas, antiguos vehículos del saber, no parecieron más que ficciones mentirosas, o cuentos de viejas; pero la tarea del mitógrafo consiste en reencontrar su contenido original".

Partiendo de este principio, Conti hace descansar la división de los mitos en las diversas enseñanzas que encierran: unos contienen los secretos de la naturaleza y otros lecciones de moral. Dentro de estos últimos se encuentra su relato de Medea (VI, 7). Se trata de hacer servir el mito a la edificación moral de los lectores por el medio de la alegoría. De esta manera, la razón del descuartizamiento y muerte del hermano e hijos de Medea se explica porque ella ha querido poner fin al apetito y a la concupiscencia "porque si alguno se permite estar enredado en los lazos de los placeres ilegítimos, de la avaricia y de la crueldad ¿cómo no va a volar lo más rápidamente de allí tomando un carro y alados dragones?". El mitógrafo tiene conciencia de la imagen negativa de Medea, pero ya sea buena o mala, es preciso, en la tradición del Ovidio moralizado que la heroína tenga su utilidad en el plano moral y religioso.

“...pero sea que nosotros tomemos a Medea por el Consejo y la Prudencia o por una mala mujer, los antiguos por esta fábula tenían la intención de dirigirnos y conducirnos a la probidad e integridad de las costumbres".

Estas palabras son claves para la lección moral que se debe retener: la carga violenta del mito ha sido transformada en beneficio de la virtud. Por otro lado, Medea, según la etimología propuesta por Conti y que está pre-

(71) Conti ante las explicaciones divergentes de los antiguos, no toma postura por ninguna de ellas y se limita por lo general a ampliar su tratado ofreciendo un resumen en el que cada dios, héroe o heroína es sucesivamente interpretado desde cada uno de los tres puntos de vista tradicionales. Cf. Seznec, reimp. 1987, 204-205. 
sente también en Calderón de la Barca, es el Consejo; es decir, siguiendo la tradición escolástica: la decisión, la elección sabia llevada a cabo después de una deliberación.

Si dejamos el renacimiento italiano y pasamos al hispano, el mitógrafo más representativo de este período fue Juan Pérez de Moya (15131596) con su Philosofia Secreta publicada en Madrid en $1585^{(72)}$. La interpretación alegórica moralizante será recurrente en su obra, pero no olvidemos que las coordenadas de la ideología que Pérez de Moya plasmará en su tratado, con sólida convicción, habían sido ya ofrecidas por el Mitologicarum liber de Fulgencio, reinterpretado y remoralizado a su vez en el siglo XV por Ridewall en el Fulgentius metaforalis ${ }^{(73)}$, por el Ovidio moralizado de Bersuire y por las Alegorias de Alberico-Neckam.

Cuando Pérez de Moya escribe su tratado mitológico además de contar con una larga tradición fuera de España que el escritor no va a desaprovechar, va a encontrar un filón inagotable en las Cuestiones del Tostado ${ }^{(74)}$, se sumergirá en la Genealogia de los dioses de Boccaccio y en tres importantes manuales mitológicos publicados en Italia entre 1548 y 1556 . Nos estamos refiriendo a la Historia de los dioses de Lilio Gregorio Gyraldi, publicada en Basilea en $1548^{(75)}$, la Mitologia de Natale Conti y Las Imágenes de los dioses de Vicenzo Cartari, publicado en Venecia en $1556^{(76)}$. A estas obras debemos añadir el importante papel que desempeña el emble-

(72) A lo largo de los siglos XVI y XVII hubo sucesivas ediciones: Zaragoza, 1599, Alcalá, 1611, Madrid, 1628 y 1673. El título con el que apareció en 1585 fue: Philosophia secreta donde debaxo de historias fabulosas se contiene mucha doctrina provechosa a todos estudios. Esta obra fue reimpresa con una introducción por Gómez de Baquero en Los clásicos olvidados, vol. VI, Madrid, 1928. Cf. la "Introducción" de Carlos Clavería a su edición de la Philosofia Secreta, Cátedra, Madrid, 1995, 13-39.

(73) H. Liebeschütz, Fulgentius metaforalis: ein Beitrag zur Geschichte der Antiken Mythologie in Mittelalter, Studien der Bibliothek Warburg IV, Leipzig-Berlín, 1926, aquí también se edita el Libellus de Alberico. Cf. Seznec, reimp. 1987.

(74) Nos referimos a los Comentarios mitológicos escritos por Alonso de Madrigal: Las XIIII questiones del Tostado, a las quatro dellas por maravilloso estilo recopila toda la Sagrada escriptura. Las otras diez questiones poéticas son acerca del linaje y sucesión de los dioses de los gentiles, Amberes, Martín Nucio, 1551. Cf. J. Fernández Arenas, "Sobre los dioses de los gentiles de Alonso Tostado Ribera de Madrigal", AEA 49, 1976, 338-343; P. Saquero-T. González, "Las Questiones sobre los dioses de los gentiles del Tostado", CFC 19, 1985, 85-99; N. Belloso Martín, Politica y humanismo en el siglo XV. El maestro Alfonso de Madrigal, el Tostado, Valladolid, 1989.

(75) Bajo el título de De deis gentium varia et multiplex bistoria in qua simul de corum imaginibus et cognominibus agitur.

(76) Lleva por título Le imagini colla sposizione degli Dei degli antichi. Cf. J.G. Graesse, Tresor des livres nares et precieux, Milán, 1950 (reimp. 1993); Seznec, reimp. 1987, 267-270, donde nos ofrece una lista bastante completa de los tratados mitológicos del Renacimiento; 
ma, como imagen que esconde un contenido moral. Destaca, en este sentido, como ya hemos indicado anteriormente, el Emblematum liber de Andrea Alciato cuya primera edición castellana no aparecerá hasta $15499^{(77)}$.

Reserva el capítulo tercero del libro IV a la figura de Medea, siguiendo un esquema similar para todos los mitos. El relato se compone de dos partes: una parte descriptiva, generalmente breve, en la que el autor traza la figura y los atributos de la heroína; y una parte moral, la más importante y extensa, en la que la figura mítica es interpretada en sentido edificante:

"Por Medea se entiende el consejo, y por esto la hacen hija de Idía, que quiere decir la que conoce. Jasón puede significar médico, de iasthe, que quiere decir curar.

Irse con él Medea, significa que el que ha de buscar medicina a su alma (que es la prudencia) para hacerse hombre bueno y prudente, ha de tener en poco todo lo demás, aunque sea lo que quiere mucho, porque el que no despreciare el deseo de los deleites y despedazare el apetito deshonesto en el camino de su vida desenfrenada, ninguna cosa puede hacer admirable ni de gloria, por lo cual se dice de Medea, como conocedora del bien, despedazó a sus hijos y a su hermano, y dejó su tierra y su padre por seguir a Jasón; y porque el que fuere sabio fácilmente señoreará a las estrellas que le convidaren a lujuria y moderará los deseos que le mueven a torpeza.

Dicen que Medea o el consejo solía sacar del cielo la Luna y las estrellas, y detener los ríos de las codicias, $y$ hacer muchas cosas que al vulgo parecian admirables, que en realidad de verdad en ningún tiempo acontecieron, y con este consejo venció Jasón el vellocino de oro. En lo que dice del remozar los viejos, es que fue la primera que halló una flor que tenía virtud de convertir los cabellos canos en negros, y esto hacía lavándolos con agua caliente del cocimiento de aquella flor. Decir que mató a Pelias fue que como fuese muy viejo y usase de este cocimiento, no lo pudiendo sufrir, murión".

Vemos cómo Pérez de Moya caracteriza a Medea a través de su nombre y del de sus progenitores. En función de ello, es el "consejo", es "la conocedora del bien", y estas cualidades le van a permitir ayudar a Jasón a buscar la prudencia. Niega la realidad de cuanto se cuenta sobre Medea

V. Infantes, "De Officinas y Polyantheas: los diccionarios y textos del Siglo de Oro", en El Siglo de Oro. Estudios y textos de literatuna atirea, Potomac (Maryland), Scripta Humanistica, 1992, 1-46.

(77) Para la tradición en nuestro país de esta obra es imprescindible consultar la edición completa de los Emblemas de Santiago Sebastián, Madrid 1985. Esta corriente de la imaginería comentada va a culminar con la Iconologia de C. Ripa publicada en Roma, en 1593, y reeditada en Madrid, en 1987, por la editorial Akal. 
que sea peculiar, que cause extrañeza ${ }^{(78)}$. Se detiene en explicar los famosos rejuvenecimientos que se le atribuyen diciendo que lo único que $\mathrm{Me}$ dea hacía era lavarlos con el agua caliente en la que se había cocido la flor que utilizaba para teńir los cabellos blancos. Medea no mató a Pelias, sino que la extrema vejez de éste no pudo soportar este procedimiento.

3.4. Para concluir, vamos a pasar a otro tipo de obras de la literatura española, el Auto Sacramental, donde el tema central y constante es la exaltación de la Eucaristía como sacrificio y como sacramento, y donde los personajes mitológicos desempeñan un importante papel en la articulación de la alegoría eucarística ${ }^{(79)}$. Concretamente nos vamos a referir al Divino Jasón, compuesto en 1634 por el poeta dramaturgo español Calderón de la Barca ${ }^{(80)}$.

Este Auto presenta la divinización de Jasón ${ }^{(81)}$ que parte con sus compańeros a la conquista del vellocino, al que convierte en símbolo de Cor-

(78) Pérez de Moya está haciendo referencia a todas esas cosas asombrosas que la Edad Media le atribuía a Medea, como por ejemplo, que convertía la luz en tinieblas, que provocaba de pronto vientos y lluvias, rayos y granizos, y terribles terremotos. Los cursos de los ríos que corrian por cauces en declive, los obligaba a fluir en retroceso hasta las partes altas y provocar inundaciones. A los árboles de hoja caduca, los hacia florecer en invierno. Al igual que rejuvenecía a los ancianos, envejecía a los jóvenes, y provocaba eclipses de Sol, cuando no existía conjunción entre éste y la Luna, etc. Todo ello aparece detallado en obras como el Roman de Troie de Benoît de Sainte-Maure (vv. 1211-2044), o en la Historia destructionis Troiae de Guido delle Colonne (libros II y III).

(79) Cf. E. Rull, Autos Sacnamentales del Siglo de Oro, Plaza y Janés, Barcelona, 1986; I. Arellano, "El Auto Sacramental", en Historia del teatro español del siglo XVII, Cátedra, Madrid, $1995,685-738$.

(80) Seguimos la edición realizada por I. Arellano y A.L. Cilveti, El Divino Jasón, Pamplona-Kassel, 1992. Sobre los Autos Sacramentales de Calderón existe una amplia bibliografia, pero por su calidad merecen citarse: A. Valbuena Prat, "Los Autos sacramentales de Calderón: Clasificación y análisis", RHi 61, 1924, 1-302; J. Páramo Pomareda, "Consideraciones sobre los Autos mitológicos de Calderón de la Barca", Thesaurus 12, 1957, 51-80; J.M. Díez Borque, "Teatro y fiesta en el Barroco español: el auto sacramental de Calderón y el público. Funciones del texto cantado", Cuadernos Hispanoamericanos 396, 1983, 223-238; A.A. Parker, Los autos sacramentales de Calderón, Ariel, Barcelona, 1983. Para comprender la alegoría en los Autos de Calderón resultan indispensables L. Fothergill Payne, La alegoria en los autos y farsas anteriores a Calderón, London, 1977 y B. Kurtz, "Defining Allegory or Troping Through Calderon's Autos", Hispanic Review 58, 1990, 227-243.

(81) El argumento abarca la misma secuencia de la leyenda que el Vellocino de Oro de Lope de Vega. A. Pociña ("Tres dramatizaciones del tema de Medea en el Siglo de Oro español: Lope de Vega, Calderón de la Barca y Rojas Zorrilla", en A. López; A. Pociña (eds.), Medeas. Versiones de un mito desde Grecia hasta hoy. Universidad de Granada, 2002, 769, n. 25) dice que la elevación alegórica de Jasón a la figura de Cristo se produce con mayor facilidad gracias a la figura de Jasón que elabora Séneca en su Medea. Cf. G. Picone; "La Medea di Séneca come fabula dell'inversiones", QCTC 4-5, 1986-87, 188-190. 
dero Místico, colgado en el árbol de Adán. En busca de ese vellocino alegórico, el alma perdida, sale Jasón acompañado de Hércules (San Pedro), Teseo (San Andrés), Orfeo (San Juan Bautista), etc. Pero la búsqueda de Jasón es doble, porque el alma está igualmente representada por Medea, igualmente alegoría de la Gentilidad, como el mismo Jasón especifica:

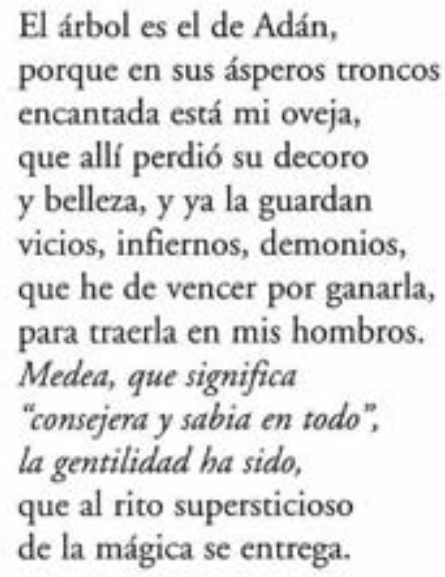

(vv. 217-229)

La empresa de Jasón será, entonces, llevarse con él a Medea sobre la nave Argo (Amor Divino), para arrancarla de la tierra de la Cólquide y de la influencia de la Idolatría, que representa, de alguna manera, la religión y la sabiduría paganas de la Antigüedad. Jasón realizará, para redimir los errores de Medea, la prueba de ir a descolgar de su árbol el vellocino, colocando en su lugar, en la cima, un Cordero que sangra y cuyo resplandor ciega y abate a la Idolatría. Medea sólo es maga de reputación, la magia está reemplazada por los milagros; el poder está en la religión a la que se tiene que convertir Medea ${ }^{(82)}$. Teniendo esto en cuenta, en el Divino Jasón se exalta la Eucaristía como rescate de la Humanidad, que es Medea, por Cristo, que es Jasón, aplicando alegóricamente la conquista del vellocino de oro, alegoría sustentada sobre motivos mitológicos ${ }^{(83)}$.

En la mayoría de los autos calderonianos es el demonio el que inventa y aplica la alegoría ordenando el material del argumento para impedir el rescate y el alimento espiritual del hombre. En el Divino Jasón, el demonio intenta contrarrestar el proyecto de un personaje antagónico (Ja-

(82) Cf. P. Brunel, Dictionnaire des Mythes Féminins, Paris, 2002, s.v. "Médée", 1281 -

(83) Cf. Mimoso-Ruiz, 1982, 140. 
són) encaminado al rescate del hombre. Las "suposiciones" del argumento pintan la peripecia de la nave Argo transportando a los argonautas por el mar a la conquista del vellocino y la lucha con la Idolatría (y con su compañero, el Mundo), que posee a Medea en calidad de "esclava y amante", hasta lograrlo con la espada de la cruz. Medea es gentilidad y también género humano perdido, es luz en el sentido que tiene tan alto valor que el mismo Hijo de Dios (Jasón) acude a rescatarla y enamorarla. En boca de Jasón, Calderón pone las siguientes palabras:

Salve, reina poderosa, destierra esa Idolatría; de tu reino la has de echar, para que pueda alumbrar sus engaños la luz mía.

(vv. 651-654)

La heroína de Calderón es "consejera y sabia en todo", siguiendo la tradición precedente de Conti y Pérez de Moya, y gracias a la intervención divina, a aquella antipática y cruel maga, que retratan Eurípides y Séneca, la convierte el dramaturgo en una simpática y bella pagana que enmienda y encarrila su vida al primer contacto con Jasón-Cristo. Difícilmente se podría imaginar una transformación más profunda del mito clásico.

En resumen, el ardiente deseo de conciliar la filosofía con la religión popular y la mitología no sólo condujo a los alegoristas, desde la Antigüedad hasta los tiempos modernos, a buscar en los dioses símbolos físicos, sino que se esforzaron también por descubrir en sus figuras y en sus nombres mismo una significación espiritual y en sus aventuras una enseñanza moral, ideología que queda patente en la figura de Medea.

Aunque la exégesis alegórica no comienza hasta el siglo VI a.C., las principales interpretaciones vertidas sobre la leyenda de Medea no aparecen hasta varios siglos después, de la mano del cínico Diógenes. Desde esta perspectiva, se aprecia un notable esfuerzo por justificar a partir del siglo IV a.C. los episodios en los que la heroína griega despliega todas sus dotes mágicas, como en las pruebas que tiene que superar Jasón en la Cólquide o el rejuvenecimiento de Pelias; para el primer ejemplo se impone una explicación alegórico-histórica, mientras para el segundo, una física: Medea es una hábil conocedora del bienestar que producen los bańos de vapor y de las propiedades de ciertas plantas para teñir los cabellos. A estas dos maneras de justificar algunos de los episodios de la historia de Medea, se viene a sumar a partir de la Edad Media la enseñanza moral que proporcionan; entonces Medea pasa a ser vista como un vicio o una vir- 
tud. Este tipo de hermenéutica se va a imponer a partir del siglo XII, alcanzando su cenit con el alegorismo eucarístico.

De todos modos, por muchas explicaciones que se le hayan querido buscar a los mitos, por mucho fondo de verdad que se haya querido ver oculto, el mito no es más que lenguaje, como ya ha expuesto en diversas ocasiones A. López Eire ${ }^{(84)}$, y al lenguaje no se le puede exigir que reproduzca la verdad, porque aunque se le exija, él no puede hacerlo, pero sí, en cambio, que exponga o saque a relucir lo instintivo o subconsciente o lo que de manera más o menos explícita o consciente es communis opinio u opinión generalizada en una sociedad que funciona con una determinada política en un momento y en un lugar determinados. El mito es indiferente a la veracidad de su mensaje como lo es el anuncio publicitario.

\section{SELECCIÓN BIBLIOGRÁFICA}

AKabar, K.H., "The Robe and the Crown: Medea's Celebration of Jason's Wedding", Mor 30-31, 1995-96, 119-125.

AlbINI, V., "Osservazzioni sulla Medea di Euripide", SIFC 14, 1996, 28-32.

BACON, J.R., The Voyage of the Argonauts, London, 1925.

Barlow, S.A., "Stereotype and Reversal in Euripides's Medea", G\&R 36, 1989, 158-171.

BARONE, C., (ed.), Euripide, futuro del teatro. La violenza nel teatro greco e latino, Atti XV e XVI Congresso Internazionale di Studi sul Drama Antico, Padova, 2002.

BongIE, E.B., "Heroic Elements in the Medea of Euripides", TAPhA 107, 1977, 27-56.

BOUVRIE, S., Women in Greek Tragedy: an Anthropological Approach, Oslo, 1990. BRELCH, A., "I figli di Medeia", SMSR 30.2, 1959, 213-254.

BUFFlêRE, F., Les mythes d'Homère et la pensée grecque, Paris, $1956\left(1973^{2}\right)$.

BurnetT, A., "Medea and the Tragedy of Revenge", CPh 68, 1973, 1-24.

Buxton, R.G.A., "Les yeux de Médée: le regard et la magie dans les Argonautiques d'Apollonios de Rodhes", en A. Moreau-J. Cl. Turpin (eds.), La magie, II, Montpellier, 2000, 265-275.

CAizzA, A., "Medea: Fortuna de un mito", Dioniso 59 (1989) 9-84; 60 (1990) 82-118; 63 (1993), 121-141; 64 (1994), 155-166.

(84) Todas estas ideas aparecen expresadas en más de una ocasión por A. López Eire, "El mito de "la otra vida y la justicia cósmica", en S. López Moreda (ed., Ideas. Contemponaneidad de los mitos clásicos, Madrid, 2002, 159-201 y "Mito, Retórica y Poética", Logo 2, 2002, 51-84. 
Claus, J.J.-Johnston, S.I., Medea: Essays on Medea in Myth, Literature, Philosophy and Art, Princeton, 1997.

Clứa SERENA, J.A., "La figura de Medea en la literatura griega: tragedia, épica y lírica", en S. López Moreda (ed.), IDEAS. Contemporaneidad de los mitos cldsicos, Madrid, 2002, 29-40.

Davidson ReID, J., The Oxford Guide to Classical Myhology in the Arts, 13001990s., s. v. "Medea", Oxford, 1993, 643-650.

DeCharme, P., La critique des traditions religieuses chez les grecs. Des origines au temps de Plutarque, Paris, 1904.

Delage, E., La géographie dans les Argonautiques d'Apollonios de Rodes, Paris, 1930.

Dominguez Garcia, V., Los dioses de la ruta del incienso. Un estudio sobre Evémero de Mesene, Oviedo, 1994.

DrÄGer, P., Argo Pasimelousa, Stuttgart (Palingenesia XLIII), 1993.

DUNN, F.M., "Euripides and the Rites of Hera Akraia", GRBS 35.1, 1994, 103-115.

EASTERLING, P.E., "The Infanticide in Euripides' Medea", YCS 25, 1977, 177 192 (= J. Mossman (ed.), Oxford Readings in Classical Studies. Euripides, Oxford, 2003, 187-200).

EPHRON, H.D., "The Jasón Tablet of Enkomi", HSCPh 65, 1961, 39-107.

Fantham, E. et al, Women in the Classical World, New York, 1995.

FORD, A., "Allegory and the Traditions of Epic Interpretation" en The Origins of Criticism. Literary Culture and Poetic Theory in Classical Greece, PrincetonOxford, 2002, 67-89.

FrenZel, E., Diccionario de Argumentos de la Literatura Universal, s.v. "Medea", Gredos, Madrid, 1976, 315-317.

GaGgadis-Robin, V., "Les images de Médée magicienne", en A. Moreau-J-CTurpin (eds.), La magie dans l'antiquité grecque tardiv. Les mythes, Université Montpellier III, 2000, 289-320.

García Gual, C., "El argonauta Jasón y Medea. Análisis de un mito y su tradición literaria", Habis 2, 1971, 85-107 (=López, A.-Pociña, A. (eds.), Medeas: versiones de un mito desde Grecia hasta hoy, vol. I, Granada, 2002, 29-48).

- "Interpretaciones de los mitos: el alegorismo y el evemerismo", en Introducción a la mitologia griega, Madrid, 1992, 193-211.

- "Jasón, el héroe que perdió el final feliz", en Mitos, viajes, héroes, Taurus, Madrid, 1996, 113-170.

Gentili, B.-Perusino, F. (eds.), Medea nella litteratura e nell' arte, Venezia, 2000.

Giannini, P., "Interpretazione della Pitica 4 di Pindaro", QUCC 31 (n.s 2), 1979, 35-63. 
Hason, J.O., "The Secret of Medea's Sucess", G\&R 12, 1965, 54-61.

HAAS, V., "Medea und Jason im Lichte hethitischen Quellen", Act.Ac.Hung 26, 1978, 241-253.

HunTER, R.L., "Short on Heroic Jasón in the Argonautica", CQ 38, 1988, 436453.

IriARTE, A., "Las razones de Medea", en J. Monleón (ed.), Tragedia griega y democracia. Medea. Encuentro mediterráneo, Extremadura, 1989, 260-271.

Jovan, F., "La figure de Médée chez Euripide, Sénèque et Corneille", en M.G. Vacchina (ed.), Attualità dell' Antico, Aosta, 1990, 181-200.

KuCH, H., Mit einer Prosa-Übertragung der Medea (Suppl. Lexis, 8), Amsterdam, 2002.

LaWALl, G., "Apollonius' Argonautica, Jasón as Anti-Hero", YCS 19, 1966, 119 169.

LEXICON ICONOGRAPHICUM MITHOLOGIAE CLASSICAE, S.V. "Medeia", vol. VI, 1992, 386-398; s.v. “Iason, vol. V, 1990, 629-638.

Llinares Garcia, M., "Mitología e iniciaciones. El problema de los Argonautas", Gerión 5, 1987, 15-42.

LOPEZ, A.-POCINA, A. (eds.), Medeas: versiones de un mito desde Grecia hasta hoy, 2 vols., Granada, 2002.

MacDermotr, E.A., Euripides' Medea: the Incarnation of Disorder, Oxford, 1989.

Maddalena, A., "La Medea di Euripide", RFIC 91, 1963, 137-138.

MATHIEU, H., Médée. Les sources de sa légende et son évolution dans la Grèce antique, 2 vols., tesis de estado, Université de Paris X, Nanterre, 1981.

MEDEIA, MELLANGES INTERDISCIPLINAIRES SUR LE FIGURE DE MÉDEE, Cahiers du GITA 2, 1986.

Medela no DRAMA ANTIGo E MODERNO, Coimbra, 1996.

MeUL, K., Odyssee und Argonautika, Berlin, 1921.

Mımoso-RuIz, D., Médée antique et moderne. Aspects rituels et socio-politiques d' un mythe, Paris, 1982,

- "Médée", en P. Brunel (ed.), Dictionnaire des mythes littéraires, Editions du Rocher, Monaco, 1988, 1008-1017.

Moreau. A., "Les mille et une facettes de Médée", Connaissance Hellènistique, 1985-87, 24-33.

- "Quelques approaches récentes du mythe de Médée", Medeia GITA 2, 1986, 109-120.

- Le Mythe de Jason et Médée: le va-un-pied et la sorcière, Paris, 1994.

Nox, B.M., "The Medea of Euripides", YCS 25, 1977, 193-225. 
Palmer, R.B., "An Apology for Jason: A Study of Euripides' Medea”, CJ 53, $1957,52$.

Pedregal Rodriguez, A., "La magia de Medea: versiones clásicas de un mito femenino", en R.M. Cid López; M. González (eds.), Mitos femeninos de la cultura clásica, Oviedo, 2003, 17-42.

PÉPIN, J., Mythe at Allegories. Les origines grecques et les contestations judeo-chretiennes, Paris, $1958\left(1976^{2}\right)$.

Petroff, J.W., Medea. A Study in the Development of a Myth, Diss., New York, 1966.

PuccI, P., The Violence of Pity in Euripides' Medea, London, 1980.

RADermacher, L., Myhtos und Sage bei den Griechen, Wien, $1938^{2}$.

RajABA, A., Women and Law in Late Antiquity, Oxford, 1996.

Rambaux, C., "Le mythe de Médée d'Euripide à Anouilh", Latomus 31, 1972, 1010-1036.

REHM, R., "Medea and the logos of the Heroic", Eranos 87, 1989, 97-115.

RENNER, R., "Medea", Blätter für das Bayerische Gymnasial-Schulwesen 1926, 32 37; 94-105; 168-177; 216-275; 326-330.

RODRIGUEZ CIDRE, E., "Mujeres deshonradas: injuria y traición en la Medea de Eurípides", Anales de Historia Antigua, medieval y Moderna 33, 2000, 37-58.

SALA, R., "Mujeres míticas: la Medea infanticida", V Jornadas sobre la Antigüedad. Mujeres de verdad y mujeres de mentira, Guipúzcoa, 1998, 19-30.

Santoni, A., Palefato. Storie incredibili, Pisa, 2000 (edición, traducción y comentario, con amplia introducción).

Sanz Morales, M., "Paléfato y la interpretación racionalista del mito: características y antecedentes", Anuario de Estudios Filológicos 22, 1999, 403-424.

- Mitógrafos griegos, Akal, Madrid, 2002 (traducción anotada).

SÉCHAN, L., "La légende de Médée", REG 40, 1927, 234-310.

SÉNAC, R., "Le retour des Argonautes d'après les Argonautiques d'Apollonios de Rodees", $B A G B$ 4, 1965, 447-476.

SEZNEC, J., Los dioses de la Antigüedad en la Edad Media y el Renacimiento, (trad. esp. reimp.) Madrid, 1987.

SuArez de la Torre, "La Medea de Eurípides", en J. Monleón (ed.), Tragedia griega y democracia. Medea. Encuentro mediterráneo, Extremadura, 1989, 239-252.

THIEL, K., Erzählumg und Beschreibung in den Argonautika des Apollonios Rhodios, Diss. Stuttgart, 1993.

- Aietes der Krieger-jason der Sieger. Zum heldenbild im hellenistischen Epos, Stuttgart, 1996. 
Uguone, R. (ed.), Medeia. Atti delle Giornate di Studio su Medea (Torino 23-24 ottobre), Torino, 1997.

VEGA VEGA, M., La figura de la hechicera y el léxico mágico de su ámbito en la literatura griega arcaica, clásica y helenistica, tesis doctoral inédita, Oviedo, 2002.

VIAN, F., "Les navigations des Argonautes: elaboration d'une légende", $B A G B 3$, 1982, 273-285.

- "Poésie et géographie: les retours des Argonautes", Académie des Inscriptions \& Belles Lettres, Paris, 1987, 249-262.

WAKOSKI, D., Medea the Sorceress, Santa Barbara, California, 1991.

WhITMAN, J., Allegory: The Dinamics of an Ancient and Medieval Technique, Oxford, 1987.

WILL, E., Korinthiaka. Recherches sur l'histoire et la civilisation de Corinthe des origines aux guerres médiques, Paris, 1955.

VV.AA., Médée et la violence, Actes du Colloque International organisé à l' Université de Toulouse-Le Mirail, 28-30 de marzo de 1996 (=Pallas 45), Toulouse, 1996. 